\title{
The Contractionary Short-Run Effects of Nominal Devaluation in Developing Countries: Some Neglected Nuances
}

\author{
by \\ Arslan Razmi \\ University of Massachusetts, Amherst \\ Revised, June 2006
}

\begin{abstract}
This paper extends the model developed by Krugman and Taylor (1978) to take into account interesting features of the evolving structure of global trade. The growing presence of transnational production chains and differential pricing behaviour of exports destined for industrial and developing countries are accommodated. Individual country and panel data pass-through estimates derived from several econometric approaches are provided to justify the latter extension. The likelihood of contractionary short-run effects of devaluations is shown to be positively related to: (1) the proportion of a country's exports destined for other developing countries, and (2) the presence of TNCs in either the export or home goods-producing sector. Unlike the Krugman-Taylor case, devaluation will generally have a contractionary impact even if: (1) trade is initially balanced, (2) consumption behaviour does not differ between wage and profit earners, and (3) the government sector has a high marginal propensity to consume in the shortrun. The resulting policy implications underline the need to take into account these increasingly important nuances of international trade while designing exchange rate policies for developing countries.
\end{abstract}

JEL Codes: F14, F41, F23, O24

Keywords: Differential pass-through elasticities, contractionary devaluations, transnational corporations, error correction models, autoregressive distributed lag models, structuralist models.

Correspondence Address: Arslan Razmi, Department of Economics, University of Massachusetts, Amherst, MA 01003, Tel: (413) 577-0785, Fax: (413) 545-2921, E-mail: arazmi@econs.umass.edu. 


\section{Introduction}

The relationship between nominal exchange rate changes and output in developing countries has been debated at length amongst academic and policy-making circles. Krugman \& Taylor (1978) developed a coherent case for possible contractionary consequences of nominal devaluations. The first part of this paper extends their original model to accommodate some of the developments that have characterised recent decades while maintaining the concision of the original framework. In particular, the extent of exchange rate pass-through is hypothesised to be greater for exports to developing countries, and the tendency to consume domestic goods out of profits is hypothesised to be lower for transnational corporations (TNCs) compared to domestic profit earners. The former hypothesis requires more careful justification in the form of empirical support. The second part of this paper, therefore, econometrically tests for the existence of significant differences in pass-through behaviour depending on whether the exported goods are destined for developing or industrialised countries.

Based on these assumptions about TNC behaviour and pass-through differences between exports to developing and industrial countries, we show that the likelihood of contractionary short-run consequences of nominal devaluation varies directly with: (1) the proportion of a country's exports destined for other developing countries, and (2) the presence of TNCs in either the export or home goods-producing sector. Moreover, devaluation is likely to have a contractionary impact even if: (1) trade is initially balanced, (2) consumption behaviour does not differ between profit and wage earners, and (3) the government sector has a high marginal propensity to consume in the shortrun. We find empirical support for the existence of systematic differences, on average, in pass-through behaviour between developing and industrialised countries. This suggestive 
finding, which is robust to several alternative empirical specifications and measures, underlines the need for policy-makers to consider related features of international trade while determining their exchange rate policies.

We make several contributions to existing literature. As mentioned earlier, the Krugman-Taylor framework is extended to take into account some interesting features of the global economy. The degree of exchange rate pass-through is estimated for a large sample of (24 developing and 19 industrialised) countries for the period 1984-2003. Differences in pass-through behaviour between developing and industrial countries are investigated. While a substantial body of literature has emerged over the years that estimates pass-through behaviour in industrial countries, developing countries have received much less attention. ${ }^{\mathrm{i}}$ Even less attention has been paid to the exploration of systematic differences in pass-through behaviour between developing and industrial countries, and to pass-through into import prices rather than into consumer prices. ${ }^{\mathrm{ii}}$ Both individual country and panel data estimates are provided. Finally, we focus on outputrelated aspects of exchange rate pass-through as opposed to many recent studies which tend to emphasise monetary policy- and inflation-related issues. ${ }^{\text {iii }}$

\section{Background and Model Set-Up}

A substantial body of literature has emerged on the possible contractionary effects of nominal devaluations in developing countries since the pioneering work of Hirschman (1949) and Diaz-Alejandro (1963). ${ }^{\text {iv }}$ Krugman and Taylor (1978) provided an elegant yet simple framework to analyze the potential short-run effects of nominal devaluations. In their framework, a devaluation can lead to short-run contraction through three channels: (i) the greater valuation effects of a devaluation on imports in the presence of a trade 
deficit and when measured in terms of the domestic currency, ${ }^{\mathrm{V}}$ (ii) a redistribution of income towards profit earners who have a higher propensity to save than wage earners, and (iii) a redistribution of revenues from the private sector to the government sector which, given a fixed level of government spending, reduces demand for the home good. This paper assumes no substitution effects in consumption or production, which may be justified by the presence of J-curve effects and the short-run nature of the model. Moreover, the paper does not distinguish between developing country exports to industrialised countries and those to other developing countries. Finally, the paper does not take into account behavioural differences between domestic profit earners and TNCs. Our paper introduces some of these features to the Krugman-Taylor model in the light of recent developments on the global scene, while maintaining the concise elegance of the original framework.

The period since the debt crisis of the early 1980s has seen a marked transformation in the export structure of developing economies. Most strikingly, manufactured products now constitute more than 70 percent of total exports from these countries. A large proportion of these exports consists of relatively low value-added, labour-intensive goods for which international elasticities of substitution are likely to be relatively high, at least in the medium to long run. Furthermore, some developing countries have seen the share of their exports going to other developing countries rise over this period. With their transformation into exporters of manufactures, many of these developing countries are likely to have acquired some ability to price discriminate, allowing for varying degrees of pass-through across destination markets.

Another major development over the last few decades has been the rising presence of TNCs in both the tradable and non-tradable, but especially the exportable goods sectors of developing economies, a case in point being the accelerated establishment of export 
processing zones (EPZs) to attract FDI and TNCs. Indeed, according to Chang (1998), TNCs now manage about 75 per cent of world trade in manufactured goods. Moreover, according to UNCTAD (2002), the shares of foreign affiliates in total exports have grown to more than 50 percent in China and 80 percent in Hungary. Considering that the consumption patterns of the owners of this international capital are not expected to directly involve domestic (host country) goods in any substantial sense, this significant increase in the presence of TNCs in international production chains calls for a more nuanced analysis of the short-run effects of nominal devaluations.

In order to focus on these new developments while keeping the analysis simple, we retain the following assumptions from the original Krugman-Taylor model:

1. There are two distinct sectors; one produces the (non-tradable) home good for domestic markets while the other produces the export good for international markets. The production of the former requires labour and imported intermediate inputs while the latter requires labour only. Both sectors use fixed coefficient technologies.

2. The price of the home good is determined by a mark-up over direct input costs, while that of the imported input is fixed in terms of the international currency.

3. The nominal wage rate is constant in terms of the domestic currency.

4. Interest rates are kept constant by action of the monetary authorities.

We extend the Krugman-Taylor model partly by assuming differential pass-through behaviour between exports to developing and industrial countries. There are several plausible reasons for expecting pricing behaviour to differ (as assumed in our theoretical model below) depending on the destination of a developing country's exports. Passthrough is likely to be positively correlated with the degree of substitutability between a country's exports and the import-substitutes produced by the trading partner. ${ }^{\mathrm{vi}}$ To the extent that developing country exports are closer substitutes for other developing country 
products, ${ }^{\text {vii }}$ pass-through into exports to other developing countries is likely, therefore, to be higher than that to industrial countries. Pass-through may be higher if the exporters are numerous relative to the domestic competitors. ${ }^{\text {viii }}$ As Campa \& Goldberg (2005) point out, one implication is that pass-through elasticities are inversely related to country real GDP. This ties in, to some extent, to the 'market share' hypothesis of firm behaviour under pricing to market. If developing country exporters are more interested in maintaining market share in industrial countries than in other developing countries, then they will be less likely to pass through the effects of currency changes to industrial country consumers than to developing country consumers. The much larger economic size of industrial country markets could motivate such a distinction. ${ }^{\text {ix }}$ Taylor (2000) explores the link between pass-through to aggregate prices and inflation within a framework of staggered pricing and monopolistic competition, arguing that regimes with higher inflation tend to have more persistent cost changes, and thus, higher exchange rate pass-through. ${ }^{\mathrm{x}}$ Devereux \& Engel (2001) argue, on a related note, that countries that have a highly volatile monetary policy ${ }^{\mathrm{xi}}$ will find their import prices being set in foreign currency, and will therefore, experience a high rate of pass-through into imported prices. To the extent that developing countries have higher inflation and less stable monetary policies, on average, their import prices would, therefore, be expected to experience higher pass-through. ${ }^{\text {xii }}$ Finally, many developing countries mainly export textiles and related products, which until recently were (and to some extent still are) subject to import quotas and non-tariff barriers in industrialised countries under the multi-fibre agreement. In the presence of such restraints, a small depreciation is likely to be absorbed by exporters in their profit margins rather than being passed through into import prices. ${ }^{\text {xii }}$

Indeed, an assumed higher pass-through into import prices is one of the factors implicitly underlying the frequently heard argument that the small open economy model 
is more applicable to developing countries. In order to accommodate this difference in pass-through behaviour, we assume that while the international currency price of exports to industrialised country markets is maintained following nominal exchange rate changes, that of exports to other developing country markets is not because domestic exporters pass the effects of such changes on to the buyers. In other words, while exporters to industrial countries engage in local currency pricing (LCP), those to developing countries engage in producer currency pricing $(\mathrm{PCP})$ when faced with exchange rate changes. Note that such a set-up implies, ceteris paribus, that while a devaluation vis-à-vis other developing countries has a negative impact on the terms of trade, that vis-à-vis industrialised countries does not. Mathematically:

$$
\begin{aligned}
& P_{X}^{D}=\left(1-t_{X}\right) P_{X} \\
& P_{X}^{I}=e\left(1-t_{X}\right) P_{X}^{*}
\end{aligned}
$$

where $P_{X}^{j}, j=\mathrm{I}, \mathrm{D}$, denote the prices (measured in domestic currency) received by domestic producers of exports to industrial and developing countries, respectively, $e$ denotes the nominal exchange rate (units of domestic currency per unit of international currency), $t_{X}$ is the ad-valorem tax rate on exports, and $P_{X}$ and $P_{X}^{*}$ are the domestic and international prices of the export good, respectively. ${ }^{\text {xiv }}$ The price of the home good, $P_{H}$, can be expressed as:

$$
P_{H}=(1+\tau)\left(w a_{H}+e P_{M}^{*} a_{M}\right)
$$

where $\tau$ is the mark-up factor, $w$ is the nominal wage, $a_{k}, k=\mathrm{H}, \mathrm{M}$, are the fixed intermediate input coefficients for labour and the imported intermediate inputs, respectively, and $P_{M}^{*}$ is the international price of the imported intermediate input. The nominal incomes of wage and profit earners, denoted by $W$ and $R$ respectively, can be 
expressed as follows:

$$
\begin{gathered}
W=w a_{H} H+w a_{X} X^{I}+w a_{X} X^{D} \\
R=\tau\left(w a_{H}+e P_{M}^{*} a_{M}\right) H+\left(P_{X}-w a_{X}\right) X^{D}+\left(e P_{X}^{*}-w a_{X}\right) X^{I}
\end{gathered}
$$

where $X^{k}, k=\mathrm{I}, \mathrm{D}$, denotes the volumes of exports to industrial and developing countries, respectively, $H$ is the output of the home good, while $a_{X}$ is the fixed labour coefficient in the export sector. Since all imports are assumed to be inputs into home good production, the latter being the only good which is consumed domestically, ${ }^{\mathrm{xv}}$ the rest of the set-up follows Krugman \& Taylor (1978). Thus, the zero excess demand conditions for the home and import goods can be expressed respectively as:

$$
\begin{aligned}
& E D H=C_{W}\left(\frac{W}{P_{H}}\right)+C_{R}\left(\frac{R}{P_{H}}\right)+G-H \\
& E D M=a_{M} H-M
\end{aligned}
$$

where $G$ denotes nominal government spending. To avoid clutter, we denote $\partial C_{W} / \partial\left(W / P_{H}\right)$ and $\partial C_{R} / \partial\left(R / P_{H}\right)$ by $\gamma_{W}$ and $\gamma_{R}$, respectively.

\section{Income Effects of Devaluation Reconsidered}

Following Krugman \& Taylor (1978), we simplify by individually considering various channels through which the income effects of a devaluation are propagated.

\subsection{Devaluation from an Initial Trade Balance}

Consider the special case where $\gamma_{W}=\gamma_{R}=\gamma$, i.e., the consumption patterns of profit and wage earners are identical functions of real income. Further, let us abstract away for now from fiscal effects by assuming that $t_{X}=t_{M}=G=0$. Considerable manipulation 
leads to the following expression for the elasticity of home goods output with respect to the exchange rate:

$$
\frac{d H}{d e} \frac{e}{H}=\frac{\gamma}{P_{H} H \Delta}\left[(1-\Lambda)\left(e P_{X}^{*} X^{I}-e P_{M}^{*} M\right)-\Lambda P_{X} X^{D}\right]
$$

where $\Lambda<1$ denotes the share of imported intermediate costs in total input costs, and $\Delta=1-\gamma_{W} \frac{w a_{H}}{P_{H}}-\gamma_{R} \frac{\tau}{1+\tau}>0$. Notice that equation (8) is identical to the expression derived by Krugman \& Taylor (1978) except for the additional term on the right hand side that results from distinguishing between exports to industrial and developing countries. The lessons that emerge regarding the consequences of a nominal devaluation are, however, qualitatively different. While the effect transmitted from the industrial country markets is expansionary, that originating from developing country markets is contractionary. The overall effect of a devaluation is contractionary barring the unlikely scenario where exports to industrialised countries are much greater than total imports and intermediate input costs as a proportion of total costs are low. Thus, what devaluation takes with one hand by raising import prices, it does not entirely give back with the other, even if trade is initially balanced. ${ }^{\mathrm{xvi}}$ Considering that the typical developing country sells a significant (and rising) proportion of its exports to other developing countries, the overall effect of a devaluation is very likely to be negative. This result is made even more probable if we note that usually countries devalue when experiencing trade deficits.

Next, suppose that TNCs completely dominate the export sector, so that profits derived from exports are not spent on consuming the home good. Then:

$$
\frac{d H}{d e} \frac{e}{H}=-\frac{\gamma W}{P_{H} H \Delta} \Lambda<0
$$

A devaluation is unambiguously contractionary in this case. The increase in import costs is not offset by the increase in nominal profits irrespective of the initial trade 
balance, although nominal income is redistributed from wages to profits. Since the same analysis holds in all three cases when it is the export sector that the TNCs dominate, we do not analyze the distributional and fiscal effects of a devaluation separately in sections 3.2 and 3.3 .

If, on the other hand, TNCs completely dominate the home goods sector then, perhaps paradoxically, the effect of a devaluation becomes ambiguous, and depends on: (i) the proportion of exports destined for each group of countries, (ii) the mark-up rate, and (iii) intermediate input costs. If exports to industrial countries are the major source of overall demand, intermediate inputs are a relatively small proportion of total costs, and the country starts with a trade surplus, then a devaluation could be expansionary. Mathematically:

$$
\frac{d H}{d e} \frac{e}{H}=\frac{\gamma}{P_{H} H \Delta}\left[(1-\Lambda) e P_{X}^{*} X^{I}-(1-\Lambda-\tau) e P_{M}^{*} M-\Lambda P_{X} X^{D}\right]
$$

If, however, trade is initially balanced, ${ }^{\mathrm{xvii}}$ a devaluation unambiguously leads to a fall in output. Mathematically, equation (10a) reduces to:

$$
\frac{d H}{d e} \frac{e}{H}=-\frac{\gamma}{P_{H} H \Delta}\left[\tau e P_{M}^{*} M+P_{X} X^{D}\right]
$$

A comparison of equations (8) and (10a) illustrates the underlying intuition. With only TNCs present in the home goods-producing sector, the increase in nominal profits due to a constant mark-up over costs 'leaks' abroad instead of stimulating domestic demand.

\subsection{Distributional Effects}

Now suppose the devaluing country starts with balanced trade but that there is a greater tendency to save out of profits than wages. Ignoring fiscal effects, the following 
expression can be derived for the exchange rate elasticity of home goods output:

$$
\frac{d H}{d e} \frac{e}{H}=\frac{W \Lambda\left(\gamma_{R}-\gamma_{W}\right)-\gamma_{R} P_{X} X^{D}}{P_{H} H \Delta}<0
$$

As in Krugman \& Taylor (1978), by shifting purchasing power from wages to profits, a devaluation serves to lower overall demand for the home good. However, the contraction follows even if consumption behaviour does not differ between the two groups. The contractionary effect is even more pronounced if TNCs are present in either or both of the two sectors. In the case where TNCs completely dominate the home goods sector, and again assuming balanced trade as the point of departure:

$$
\frac{d H}{d e} \frac{e}{H}=\frac{\Lambda}{P_{H} H \Delta}\left[\left(\gamma_{R}-\gamma_{W}\right) W-\gamma_{R}\left(\tau e P_{M}^{*} M+P_{X} X^{D}\right)\right]
$$

The extent to which the contractionary effect is magnified by the presence of TNCs in the home goods sector varies directly with the (imported) input intensity of home goods' production.

\subsection{Fiscal Effects}

Assuming that the government sets its expenditures and tax rates at the beginning of the period, and further assuming a balanced budget, yields the following expression:

$$
\frac{d H}{d e} \frac{e}{H}=-\frac{\gamma}{P_{H} H \Delta}\left[t_{x} e P_{X}^{*} X^{I}+P_{X} X^{D}\right]<0
$$

where we assume balanced trade and $\gamma_{W}=\gamma_{R}=\gamma$. A devaluation shifts income from the private sector to the government, which has a marginal propensity to consume of zero. The effect on output complements the contractionary effect emanating from lower profits from sales to developing countries. The presence of TNCs in the home goods sector does not affect the analysis since that sector is not subject to export taxes. 
In summary, complete (or higher) exchange rate pass-through into prices of exports destined for other developing countries increases the likelihood of output contraction following a nominal devaluation. The presence of TNCs in either sector generally further enhances such a likelihood.

\section{Nominal Devaluation and Price Adjustment}

A number of studies have explored the relationship between exchange rate changes and the price of tradables. Few studies, however, have focused on developing countries. Even fewer have systematically investigated differences in pass-through behaviour between industrial and developing countries. As discussed in section 2, there are several plausible reasons for expecting pricing behaviour to differ depending on the destination of a developing country's exports. Furthermore, assuming relatively greater pass-through into export prices for goods destined for other developing countries, it follows from the theoretical model developed in sections 2 and 3 that the contractionary short-run effect of a devaluation varies directly with the share of such exports in a country's total exports. The next two sections empirically explore pass-through behaviour for exports to industrialised and developing countries using several different individual country and panel data approaches. We find support for the hypothesis that exchange rate passthrough is markedly higher, on average, for exports to developing countries.

\section{Empirical Models and Sample}

Our empirical strategy consists of two stages. In the first stage, we seek to investigate the possible existence of systematic differences between the pass-through behaviour of exports destined for individual developing and industrial countries. In the second stage, 
we pool the data into two groups; one for developing countries and the other for industrial countries. The findings are consistent with those originating from the individual country studies.

Ideally, we would like to have import prices for transactions among pairs of countries in order to see the correspondence between changes in these and the bilateral nominal exchange rates. However, such data are not readily available for most developing countries. An alternative is to study correlations between nominal exchange rate and export price changes for each country. However, this approach would not yield any information regarding differences between pass-through into developing versus industrialised country import prices. Yet another alternative is to estimate pass-through into import prices. Although this approach does not distinguish between imports coming from developing and industrial countries, it helps address the aims of our study more directly. We therefore, use the latter approach to investigate systematic differences in pass-through behaviour for imports into countries at different levels of income.

Our sample consists of 24 developing and 19 industrial countries. ${ }^{\text {xviii }}$ All the countries for which import price or unit import value data were available from the International Monetary Fund's International Financial Statistics (IFS) are included. ${ }^{\text {xix }}$ The sample spans the period 1984-2003. The choice of the start year is designed to exclude the debt crisis of 1982-83.

We explored the time series properties of our variables, with the help of the Augmented Dickey-Fuller (ADF) test. The results, which are reported in Table 1, indicate that an overwhelming number of individual country series are non-stationary, and integrated of order one, i.e., I(1), at the traditional levels of statistical significance. ${ }^{\mathrm{xx}}$ In carrying out our analysis, we therefore, pursued three approaches: (1) an autoregressive distributed lag (ADL) model, (2) an error correction approach with 
unknown long-run (cointegrating) coefficients, and (3) an error correction approach that assumes complete pass-through in the long run. While we only report the results from the first and second approaches, those from the third approach were virtually identical, and are available on request. The ADL model can be expressed as follows:

$$
\Delta P_{M i, t}=\beta_{0 i}+\sum_{p=0}^{n} \beta_{1 i, p} \Delta E_{i, t-p}+\sum_{p=0}^{n} \beta_{2 i, p} \Delta P_{i, t-p}^{*}+\sum_{q=1}^{n} \beta_{3 i, q} \Delta P_{M i, t-q}+\sum_{p=0}^{n} \varepsilon_{i, t-p}
$$

where, for the $i^{\text {th }}$ country, $P_{M}$ is the import price (in the importer's currency), $E$ is the nominal exchange rate (importer's currency per US dollar), while $P^{*}$ denotes the exporting country's unit production costs (in terms of US dollars). All variables are in logs and the series used have an annual frequency. The specification in first differences reflects our focus on short-run pass-through behaviour and its consequences for the shortrun relationship between devaluations and output changes. ${ }^{\mathrm{xxi}}$ The reason for the inclusion of the nominal exchange rate on the right hand side of equation (14) is obvious. A brief explanation for the other explanatory variables is in order. An increase in a country's import price transmitted from relative price changes abroad may be due either to changes in the bilateral nominal exchange rate or to changes in the cost structure abroad. ${ }^{\text {xii }}$ The inclusion of the foreign price level (world CPI as a proxy for world production costs) controls for the latter, allowing us to isolate the effects of nominal exchange rate changes. Finally, although we use variables in their first differences, the possibility of persistence or inertial effects of external shocks suggests the addition of lagged differenced values of the dependent variable. As a robustness check, we re-estimate exchange rate passthrough elasticities with the domestic price level added as an explanatory variable. ${ }^{\text {xiii }}$ As a further robustness check, we re-estimate using the International Monetary Fund's 'Special Drawing Rights' (SDR) as the unit of value instead of the dollar. The results, which are reported in the next section, are found to be qualitatively robust. 
While the ADL approach is useful for our purposes given the length of our time series, it does not explicitly take into account the possible existence of long-run cointegrating relationships between the levels of the regressors. We therefore, derived another set of estimates after embedding a hypothesised long-run relationship between the levels of the variables in an error correction framework in order to investigate short-run reversion to equilibrium. The specification can be expressed in its general form as follows:

$$
\Delta P_{M i, t}=\theta_{0 i}+\sum_{p=0}^{n} \theta_{1 i, p} \Delta E_{i, t-p}+\sum_{p=0}^{n} \theta_{2 i, p} \Delta P_{i, t-p}^{*}+\theta_{3 i} E_{i, t-1}+\theta_{4 i} P_{i, t-1}^{*}+\theta_{5 i} \varepsilon_{i, t-1}+\varepsilon_{i, t}
$$

where $\varepsilon_{i, t-1}=P_{M i, t-1}-E_{i, t-1}-P_{i, t-1}^{*}$ captures the hypothesised long-run relationship between the price of imports, the nominal exchange rate, and international production costs, while $\theta_{5 i}$ is the error correction coefficient. ${ }^{\text {xxiv }}$

Finally, we apply another version of the error correction approach which assumes homogeneity in exchange rates and prices, or in other words, unit long-run cointegrating coefficients:

$$
\Delta P_{M i, t}=\phi_{0 i}+\sum_{p=0}^{n} \phi_{1 i, p} \Delta E_{i, t-p}+\sum_{p=0}^{n} \phi_{2 i, p} \Delta P_{i, t-p}^{*}+\phi_{3 i} \varepsilon_{i, t-1}+\varepsilon_{t}
$$

where $\phi_{3}$ is the error correction coefficient. This approach implicitly assumes long-run reversion towards purchasing power parity, or alternatively, towards a fundamental real exchange rate. The results, although not reported here, are available from the author on request.

$<$ INSERT TABLE 1 ABOUT HERE >>

\section{Econometric Results}

This section discusses the results of our econometric analysis of individual country and panel data for 43 countries. 


\subsection{Individual Country Estimates}

\section{The ADL Approach}

Table 2 presents estimates for 24 developing countries. Considering the relatively short length of our time series, the individual country model is specified in contemporaneous first differences throughout. The pass-through estimates have the expected (positive) sign and magnitude (between 0 and 1) for most countries. However, the magnitudes of the pass-through coefficient for China, Hong Kong, South Korea, and Sri Lanka are much greater than one. Moreover, the pass-through coefficient for Singapore is negative. Finally, India and Pakistan report negative adjusted coefficients of determination. These countries are, therefore, excluded while reporting averages. Of the remaining 17 countries, 11 report pass-through estimates of greater than 0.5 , indicating that exporters to these countries pass through most of the impact of nominal devaluations within a year. The coefficient (for estimates that are significant at the 5 percent level) ranges from 0.324 for South Africa to 1.019 for Argentina. The coefficient on the world price level variable is generally much lower in magnitude suggesting that most of the increase in import prices originates in exchange rate changes rather than in changes in global production costs. The coefficient of the lagged import price term is generally not significant at the conventional levels, indicating weak inertial effects. ${ }^{\mathrm{xx}}$ The adjusted coefficients of determination are generally high enough to inspire confidence in the results.

Table 3 presents the results for 18 industrialised countries. Individual country estimates could not be derived for the US for obvious reasons. ${ }^{\mathrm{xxvi}}$ The pass-through estimates have the expected sign and magnitude for almost all the countries. However, the coefficient for New Zealand is much greater than one. The estimated pass-through 
elasticity for Norway is negative. These two countries are, therefore, excluded while reporting averages. Of the remaining 16 industrial countries, only three report passthrough estimates of greater than 0.5 , indicating that exporters to these countries mostly accommodate nominal exchange rate changes in their margins, at least in the short run. The coefficients (for estimates that are significant at the 5 percent level) range from 0.267 for Denmark to 0.964 for Japan. Again, the coefficient of the world price level variable is generally much lower in magnitude suggesting that most of the increase in import prices originates in nominal exchange rate changes rather than in changes in global production costs. For most countries, the coefficient of the lagged import price term is not statistically significant at the conventional levels, indicating weak inertial effects.

As noted above, a much greater proportion of developing countries report a passthrough elasticity of greater than 0.5 in magnitude. Further comparison of the two sets of estimates for industrial and developing countries indicates that the mean value of the nominal exchange rate coefficient is markedly greater for the group of developing countries. Excluding the seven developing countries which either report negative nominal exchange rate pass-through elasticities, yield coefficients that are greater than 1.25 in absolute value, or report negative adjusted coefficients of determination, yields averages of 0.643 for the exchange rate coefficient and 0.230 for the world price coefficient for the 17 remaining developing countries. ${ }^{\text {xxii }}$ Excluding individual industrial countries on the same grounds yields averages of 0.422 for the exchange rate coefficient and 0.199 for the world price coefficient for the 16 remaining industrial countries. ${ }^{\text {xxviii }}$ Finally, further excluding countries that reported exchange pass-through coefficients that are not significant at the 5 percent level yields averages of 0.714 and 0.170 for developing countries and 0.479 and 0.121 for industrial countries, respectively. ${ }^{\text {xxix }}$ Thus, exchange rate pass-through elasticities are much higher, on average, for developing 
countries. The correlation coefficient between the estimated pass-through elasticities and the GDP per capita (averaged over the sample period) of individual countries is -0.25 , providing further support to our hypothesis.

$<<$ INSERT TABLES 2 and 3 ABOUT HERE $>>$

Diagnostic tests (not reported here but available on request) including the Jarque-Bera statistics, the Breusch-Godfrey LM tests for serial correlation in the residuals, and LM tests for Autoregressive Conditional Heteroscedasticity $(\mathrm{ARCH})$ in the residuals, ${ }^{\mathrm{xxx}}$ do not indicate major problems at the 5 per cent level of significance. Only the residuals from the New Zealand and Venezuela equations indicate serial correlation. Furthermore, estimates for India and Poland indicate autoregressive conditional heteroscedasticity. The residuals for Hungary, Poland, and Finland indicate violation of the normality assumption. Reassuringly, CUSUM test plots do not suggest parameter instability with the exception of India. ${ }^{\text {xxi }}$

Controlling for domestic competition: Some previous studies have controlled for the effects of competition from domestic producers of import-substitutes in the importing countries by including a domestic producer price index variable as a regressor. However, such data are not available for many developing countries in our sample. We therefore, carried out a robustness check by adding the domestic consumer price index for each importing country as a regressor instead. The addition of the additional control variable does not qualitatively change the results. However, considering that we use annual data, the domestic CPI is likely to be highly correlated with the nominal exchange rate. We therefore, only report results for regressions run without this control variable. ${ }^{\text {xxii }}$ Using SDRs instead of US dollars: One potential drawback of using the dollar as the 'benchmark' exchange rate for both nominal exchange rates and the world price level is 
that the variation in pass-through estimates could be a function of the share of an individual country's imports from the US. For example, while Mexico purchased 64 percent of its imports from the US in 2003, the corresponding statistic for Poland was less than 2 percent. $^{\text {xxxiii }}$ However, to the extent that a large proportion of international trade that does not involve the US is nevertheless denominated in US dollars, these statistics radically understate the use of the dollar in international trade. That the dollar remains the vehicle currency of choice for international transactions (especially for developing country traders), provides justification for its use as the benchmark. However, to further test the robustness of our conclusion that nominal exchange rate pass-through is higher on average for developing countries, we re-estimated individual country pass-through equations using a weighted nominal exchange rate index, namely the International Monetary Fund's reserve asset known as the SDR. ${ }^{\text {xxiv }}$ The SDR is based on a basket consisting of the five key international currencies, the US dollar, the pound sterling, the yen, the Deutsche mark, and the French franc. ${ }^{\mathrm{xxxv}}$

The average estimated exchange rate pass-through coefficients were somewhat close to the earlier dollar estimates. Furthermore, exchange rate pass-through elasticities were higher, on average, for developing countries, although the difference between the two groups of countries was somewhat smaller than in the other sets of estimates. The correlation coefficient between the estimated pass-through elasticities and the GDP per capita (averaged over the sample period) of individual countries was -0.35 . $^{\text {xxvi }}$

\section{The Error Correction Approach}

Tables 4 and 5 present estimates for 24 developing and 18 industrial countries,

respectively. ${ }^{\mathrm{xxvii}}$ The short-run pass-through estimates have the expected sign and magnitude for most countries. The coefficient of the lagged error correction term is 
correctly signed in all cases, indicating reversion to equilibrium over time, although it is not statistically significant in many instances. ${ }^{\text {xxxviii }}$ The latter observation is not surprising given the relatively short length of our time series.

Again, a much greater proportion of developing countries reports a pass-through coefficient of greater than 0.5 in magnitude. Excluding countries which either report negative or insignificant (at the 5 percent level) nominal exchange rate pass-through elasticities, yield coefficients that are greater than 1.25 in absolute value, or report negative adjusted coefficients of determination, yields averages of 0.722 and 0.432 for developing and industrial countries, respectively. Thus, the results are quite similar to those yielded by the ADL approach. In particular, exchange rate pass-through coefficients are much higher, on average, for developing countries. The correlation coefficient between the estimated pass-through coefficients and the GDP per capita of individual countries (averaged over the sample period) was -0.33 .

Using SDRs instead of US dollars: As another robustness test, we pursued the error correction approach to derive regression results with variables defined in terms of the SDR. Again, estimated exchange rate pass-through coefficients were much higher, on average, for developing countries. Also, the error correction terms were correctly signed, although in many cases, statistically insignificant. The correlation coefficient between the estimated pass-through coefficients and the GDP per capita (averaged over the sample period) of individual countries was $-0.44 .^{\text {xxxix }}$

$<$ INSERT TABLES 4 and 5 ABOUT HERE >>

\subsection{Panel Data Estimates}

In order to increase the number of degrees of freedom available, and to investigate 
possible lagged effects, we next pool the data into panels, one each for developing and industrialised countries. In addition to the above-mentioned benefits, pooling generally also reduces collinearity among the regressors, thus increasing the efficiency of the estimates (Hsiao, 2003). An obvious drawback of pooling is the imposition of the rather stringent condition that the coefficients be the same across members. We used a Chow test of the joint restrictions $\left(H_{0}: \beta_{1 i}=\beta_{1} \cup \beta_{2 i}=\beta_{2} \cup \beta_{3 i}=\beta_{3}\right)$ in equation (14) in order to investigate whether the data for the developing and industrialised countries in our sample can be pooled together in separate panels. The null hypothesis of poolability was rejected in both cases at the conventional levels of statistical significance. However, although pooled estimation may introduce some bias in this case, it is still likely to be more efficient. ${ }^{\mathrm{xl}}$ Moreover, since we are mainly interested in differences in behaviour, and there is no obvious reason why pooled estimates for one set of countries would be more biased than those for the other, pooling offers an important test of the robustness of our overall results. This section therefore, presents the panel data estimates. Panel data unit root tests indicated that all the series are I(1), with the exception of the nominal exchange rate series for developing countries which was found to be $I(2){ }^{x l i}$ Table 6 reports the results derived from the ADL approach. We specify the empirical model as an autoregressive distributed lag model of order one, utilising a least squares dummy variable (fixed effects) model to incorporate country-specific unobserved heterogeneity.

As seen from columns (2) and (3) of Table 6, which report dollar regressions for the period 1984-2003, the panel data estimates support our earlier finding of significantly higher exchange rate pass-through elasticities for imports into developing countries. ${ }^{\text {xlii }}$ The estimated coefficients for the contemporaneous nominal exchange rate are 0.906 and 0.425 for developing and industrial countries, respectively. ${ }^{\text {xliii }}$ Moreover, taking into 
account lagged effects does not noticeably affect the divergence between the two nominal exchange rate pass-through elasticities. ${ }^{\text {xliv }}$ The coefficient for the developing country panel is higher than that found for most individual developing countries. The contemporaneous coefficient on the world price level is much greater for the industrial country group. The adjusted coefficient of determination is much higher for the developing country panel indicating that the specified variables do a much better job of explaining variation in import prices for the developing country group.

Retracing the robustness checks employed for the individual country estimates, we next re-estimated the panel specifications for industrial and developing countries using SDR units instead of US dollars. Columns (4) and (5) of Table 6 present the results. The countries whose currencies are included in the calculation of the SDR (Germany, Japan, US, and UK) were excluded to mitigate possible simultaneity concerns. The estimated exchange rate coefficients are quite similar to the previous (dollar-based) ones for both groups of countries, although the estimated coefficient for industrialised countries is somewhat higher. The coefficients of the contemporary nominal exchange rate term are 0.887 and 0.474 for developing and industrial countries, respectively, while those for contemporary world price are 0.525 and 0.249 respectively. Again, taking into account lagged effects does not noticeably affect the divergence between the exchange rate passthrough elasticities. Notice that the lagged pass-through coefficients are generally not significant at the 5 percent level, irrespective of the currency unit used.

As a sensitivity test, and in order to explore any changes in behaviour over time, we split the sample into two periods, 1984-1993 and 1994-2003. Columns (7)-(15) present the estimates. The contemporaneous pass-through estimates are remarkably stable across time periods and currency units, although the gap between the two sets of pass-through estimates increased between the two periods. Recently, Taylor (2000) has suggested that 
pass-through elasticities have declined in response to a less inflationary environment world-wide, leaving firms more willing to accommodate small price changes in their margins. We find supportive evidence only for industrial countries. Indeed, in the case of developing countries, pass-through appears to have increased. ${ }^{\text {xlv }}$ More conclusive results, however, must await a more exhaustive treatment that takes into account the evolution of inflationary expectations. ${ }^{\text {xlvi }}$

Table 7 reports the results derived from the error correction approach. As seen from columns (2) and (3), which report regressions for the period 1984-2003, the panel data estimates support our finding of higher exchange rate pass-through elasticities for imports into developing countries. Using the US dollar as the unit of measure, the estimated coefficients of the contemporary nominal exchange rate are 0.919 and 0.442 for developing and industrial countries, respectively. Columns (4) and (5) of Table 7 present the SDR-based estimates. The estimated short-run exchange rate coefficients are virtually identical to the dollar estimates. Columns (7)-(15) present the estimates for the sub-periods. The short-run pass-through estimates are even more stable across time periods and currency units than in the dollar-based estimates. Again, short-run passthrough into industrial country import prices appears to have declined in the second period. The error correction coefficients are correctly signed in all instances and statistically significant at the 5 percent level in almost half of the cases. The range of estimated values of these coefficients indicate reasonably rapid reversion, suggesting that about 20-40 percent of the effect of a disequilibrating shock is removed within a year.

Finally, as another robustness check, we estimated panel equations while taking into account time-specific effects in addition to cross-section fixed effects. The estimates, which are available from the author on request, remain essentially unchanged.

In brief, all sets of panel data estimates ${ }^{\text {xlvii }}$ indicate higher nominal exchange rate pass- 
through into developing country import prices. This in light of our theoretical model reinforces the theoretical possibility that devaluations are more likely to be contractionary in the short-run than suggested originally by Krugman \& Taylor (1978).

$<<$ INSERT TABLES 6 and 7 ABOUT HERE $>>$

\section{Concluding Remarks}

The objective of the first part of this paper was to extend the framework developed by Krugman \& Taylor (1978) for analyzing the short-run effects of a nominal devaluation on the level of output of a semi-industrialised developing economy. In doing so, we have attempted to incorporate some recent developments in the international economy while maintaining the simplicity of the original framework. We assume that exchange rate pass-through is higher for developing country exports sold to other developing countries. Moreover, owners of TNCs are likely to consume a much smaller proportion of their earnings in the host country than the owners of host country firms. Some of the interesting findings emerging from the extended theoretical framework can be summarised as follows:

- The likelihood of contractionary short-run consequences of a devaluation varies directly with: (1) the proportion of a country's exports destined for other developing countries, and (2) the presence of TNCs in either the export or home goods-producing sector. $^{\text {xlviii }}$

- Unlike the original Krugman-Taylor framework, a devaluation will generally have a contractionary impact even if: (1) trade is initially balanced, (2) consumption behaviour does not differ between wage and profit earners, and (3) the government sector has a high marginal propensity to consume in the short-run. 
- As long as the government sector's marginal propensity to consume in the short-run is lower than that of the domestic profit earners, the likelihood of a negative fiscal effect following a devaluation varies inversely with the presence of TNCs in the export sector.

- Interestingly enough, the presence of TNCs in the export sector is more likely to result in a contraction of demand (and thus, of output) following a devaluation than their presence in the home goods-producing sector. This is because increased profits for domestic exporting firms from sales to industrialised countries may make up for the fall in demand originating from other sources.

Thus, our extended model indicates that some evolving features of global trade and production make the short-run effects of a devaluation much more likely to be contractionary than suggested originally by Krugman \& Taylor (1978). The postulated difference between exchange rate pass-through into prices of goods exported to developing and industrialised countries is empirically explored in the second part with the help of individual country and panel data regressions. The main finding emerging from the estimates is that developing country imports exhibit higher pass-through elasticities. Moreover, this conclusion is robust to different methodologies, specifications and units of account. Thus, a major policy lesson that emerges from our study is that the short-run consequences of a nominal devaluation for output may vary depending on whether it is relative to other developing or industrial countries, and on the composition of a country's export markets. Developing countries that have a major presence of TNCs, and that sell a major share of their exports to other developing countries, face an increased likelihood of short-run contractionary effects of nominal devaluations.

Our empirical study should be seen as a preliminary exploration of an intriguing 
possibility raised by our extension of the Krugman-Taylor model. One limitation of our study is that, in order to maintain the conciseness of the original Krugman-Taylor framework, it assumes away substitution effects of price changes on trade volumes, thus focusing on the short run and almost certainly overstating structural inertia in developing countries. Such substitution effects are likely to appear both in production and consumption. On the production side, substitution effects are likely to be much stronger for exports to industrialised countries given that, due to greater pass-through, a devaluation has a much lower effect on profits for exporters selling to developing countries. On the other hand, and to the extent that developing country exports are closer substitutes for domestic production in other developing countries, substitution in consumption is likely to be greater for imports into those countries. Thus, substitution effects in consumption and production are likely to counteract each other (to a lesser or

greater degree), as far as the destination of exports is concerned. ${ }^{\text {xlix }}$ Another limitation of our study is that it either uses US dollars or IMF's SDR as units of account. However, to the extent that the dollar is the currency of choice for international trade, and that the currencies included in the SDR cover an overwhelming proportion of international transactions, this limitation is mitigated. Finally, an extended study of differences in pass-through behaviour between industrialised and developing countries will take into account additional factors such as scale economies, asymmetric responses to appreciations and depreciations, variable mark-up behaviour, and unit labour costs.

\section{Data Items and Sources}

$E$ Bilateral nominal exchange rates in US dollar terms obtained from the International 
Monetary Fund's International Financial Statistics (IFS) database, with the exception of Taiwan for which data were obtained from the web site of the Central Bank of China. SDR data obtained from IFS.

$P_{M}$ Import prices or unit import values. Aggregated values were obtained from the IFS with the exception of Taiwan, Mexico, and China for which the values were obtained from the Taiwanese Directorate-General of Budget, Accounting, and Statistics, the Bank of Mexico, and the World Bank, respectively.

$P^{*}$ World consumer price index obtained from IFS.

$P$ Consumer price indices obtained from IFS. For Taiwan, these data were obtained from the Taiwanese Directorate-General of Budget, Accounting, and Statistics.

GDPPC GDP per capita obtained from the World Bank's World Development Indicators. For Taiwan, the series was obtained from the Taiwanese Directorate-General of Budget, Accounting, and Statistics. 
Table 1: Augmented Dickey-Fuller (ADF) Test Statistics for Individual Countries

\begin{tabular}{|c|c|c|c|c|c|c|}
\hline & \multicolumn{6}{|c|}{ Variable } \\
\hline & $P_{M}$ & $E$ & $P^{*}$ & $\Delta P_{M}$ & $\Delta E$ & $\Delta P^{*}$ \\
\hline Argentina & -0.598 & -0.238 & -0.874 & -4.259 & -4.565 & -1.782 \\
\hline Australia & -2.805 & -2.778 & & -3.420 & -3.665 & \\
\hline Belgium-Luxemburg & -6.781 & 2.020 & & & -3.385 & \\
\hline Brazil & 1.725 & -2.020 & & -3.418 & -1.896 & \\
\hline Canada & -1.510 & 0.259 & & -1.374 & -2.122 & \\
\hline Chile & -0.773 & 4.386 & & -5.971 & -2.136 & \\
\hline China & -1.445 & 1.255 & & -4.399 & -3.866 & \\
\hline Colombia & 5.123 & 2.647 & & -1.389 & -0.893 & \\
\hline Denmark & -1.710 & -2.693 & & -3.468 & -3.221 & \\
\hline Finland & -1.495 & -3.401 & & -4.335 & & \\
\hline Germany & -2.500 & -2.815 & & -4.602 & -3.659 & \\
\hline Greece & -2.144 & -1.595 & & -3.244 & -3.065 & \\
\hline Hong Kong & -2.910 & -1.318 & & -2.382 & -3.218 & \\
\hline Hungary & -0.644 & -3.592 & & -2.254 & & \\
\hline Iceland & -1.993 & -0.836 & & -2.599 & -5.279 & \\
\hline India & 0.183 & -0.349 & & -3.459 & -3.022 & \\
\hline Ireland & -1.754 & -2.557 & & -4.127 & -3.983 & \\
\hline Italy & -0.577 & -1.745 & & -4.624 & -3.835 & \\
\hline Japan & -3.022 & -2.927 & & -6.629 & -4.360 & \\
\hline Jordan & -5.193 & -3.636 & & & & \\
\hline Kenya & 0.605 & -0.565 & & -4.782 & -3.989 & \\
\hline Korea & -1.032 & -1.062 & & -5.189 & -4.269 & \\
\hline Mauritius & 3.445 & 0.110 & & -3.461 & -2.993 & \\
\hline Mexico & -0.036 & -0.351 & & -3.122 & -3.196 & \\
\hline Morocco & -1.690 & -1.664 & & -3.707 & -3.595 & \\
\hline Netherlands & -3.162 & -2.808 & & & -3.659 & \\
\hline New Zealand & -3.387 & -3.367 & & & & \\
\hline Norway & -3.011 & -1.479 & & & -3.151 & \\
\hline Pakistan & 3.167 & 0.360 & & -3.934 & -2.778 & \\
\hline Philippines & -0.222 & N/A & & -3.588 & N/A & \\
\hline Poland & -0.141 & -0.449 & & -2.354 & -3.071 & \\
\hline Portugal & -2.041 & -1.942 & & -5.295 & -4.281 & \\
\hline Singapore & -2.476 & -2.589 & & -4.393 & -2.256 & \\
\hline South Africa & 1.591 & 3.414 & & 3.209 & -3.212 & \\
\hline Spain & -2.794 & -1.743 & & -4.208 & -3.421 & \\
\hline Sri Lanka & 0.720 & 2.336 & & -2.444 & -2.280 & \\
\hline Sweden & -0.245 & -1.500 & & -4.348 & -3.025 & \\
\hline Syria & -1.603 & N/A & & -4.022 & N/A & \\
\hline Taiwan & -2.438 & -1.953 & & -2.682 & -2.747 & \\
\hline Thailand & -0.011 & -0.501 & & -1.594 & -3.847 & \\
\hline Turkey & 8.929 & -2.430 & & 4.100 & 6.088 & \\
\hline UK & -1.465 & -2.480 & & -3.063 & -3.580 & \\
\hline US & -3.167 & N/A & & & N/A & \\
\hline Venezuela & 3.431 & 4.514 & & 1.237 & -0.885 & \\
\hline
\end{tabular}

The reported results are based on the following regression:

$$
\Delta x_{t}=\mu_{1}+\mu_{2} x_{t-1}+\sum_{t=1}^{n} \gamma_{i} \Delta x_{t-1}+v_{t}
$$

Lag lengths based on Schwarz Information Criterion. The 1, 5, and 10 percent critical values for most series are $-3.89,-3.05$, and -2.67 , respectively. Results for first-differences not presented where the series is found to be $\mathrm{I}(0)$. N/A indicates 'not available' due to singularity issues. 
Table 2: Pass-Through Estimates for Developing Countries Using the Autoregressive Distributed Lag (ADL) Approach (US dollars, 1984-2003)

\begin{tabular}{|c|c|c|c|c|c|c|}
\hline Country & Constant & $\Delta E_{t}$ & $\Delta P_{t}^{*}$ & $\Delta P_{M, t-1}$ & Adj. $R^{2}$ & St. Error \\
\hline Argentina & $\begin{array}{l}-0.034 \\
(-2.04)\end{array}$ & $\begin{array}{c}1.019 \\
(102.4)\end{array}$ & $\begin{array}{c}0.222 \\
(1.546)\end{array}$ & $\begin{array}{l}-0.014 \\
(-1.25)\end{array}$ & 0.999 & 0.034 \\
\hline Brazil & $\begin{array}{l}-0.051 \\
(-0.68)\end{array}$ & $\begin{array}{c}0.967 \\
(16.30)\end{array}$ & $\begin{array}{c}0.498 \\
(0.373)\end{array}$ & $\begin{array}{c}0.054 \\
(1.062)\end{array}$ & 0.989 & 0.128 \\
\hline China & $\begin{array}{l}-0.007 \\
(-0.13)\end{array}$ & $\begin{array}{c}2.039 \\
(5.764)\end{array}$ & $\begin{array}{l}(0.373) \\
(-0.66)\end{array}$ & $\begin{array}{c}0.065 \\
(0.569)\end{array}$ & 0.788 & 0.104 \\
\hline Chile & $\begin{array}{c}0.054 \\
(2.365)\end{array}$ & $\begin{array}{c}0.543 \\
(4.782)\end{array}$ & $\begin{array}{c}0.050 \\
(0.394)\end{array}$ & $\begin{array}{l}-0.212 \\
(-3.13)\end{array}$ & 0.688 & 0.020 \\
\hline Colombia & $\begin{array}{c}0.017 \\
(0.626)\end{array}$ & $\begin{array}{c}0.473 \\
(2.488)\end{array}$ & $\begin{array}{c}0.173 \\
(0.982)\end{array}$ & $\begin{array}{c}0.214 \\
(0.913)\end{array}$ & 0.604 & 0.042 \\
\hline Hong Kong & $\begin{array}{l}-0.029 \\
(-2.15)\end{array}$ & $\begin{array}{c}6.106 \\
(1.641)\end{array}$ & $\begin{array}{c}0.289 \\
(2.676)\end{array}$ & $\begin{array}{c}0.268 \\
(1.231)\end{array}$ & 0.413 & 0.024 \\
\hline Hungary & $\begin{array}{c}0.016 \\
(0.419)\end{array}$ & $\begin{array}{c}0.617 \\
(3.099)\end{array}$ & $\begin{array}{c}0.296 \\
(1.080)\end{array}$ & $\begin{array}{c}0.019 \\
(0.092)\end{array}$ & 0.433 & 0.076 \\
\hline India & $\begin{array}{c}0.031 \\
(0.545)\end{array}$ & $\begin{array}{c}0.484 \\
(1.119)\end{array}$ & $\begin{array}{c}0.052 \\
(0.130)\end{array}$ & $\begin{array}{l}(0.063) \\
(-0.24)\end{array}$ & -0.107 & 0.106 \\
\hline Jordan & $\begin{array}{c}0.007 \\
(0.175)\end{array}$ & $\begin{array}{c}0.992 \\
(5.263)\end{array}$ & $\begin{array}{l}(0.014) \\
(-0.04)\end{array}$ & $\begin{array}{c}0.101 \\
(0.642)\end{array}$ & 0.648 & 0.082 \\
\hline Kenya & $\begin{array}{c}0.013 \\
(0.382)\end{array}$ & $\begin{array}{c}0.691 \\
(7.187)\end{array}$ & $\begin{array}{c}0.482 \\
(1.850)\end{array}$ & $\begin{array}{l}(0.396) \\
(-2.95)\end{array}$ & 0.806 & 0.055 \\
\hline Korea & $\begin{array}{c}0.028 \\
(1.024)\end{array}$ & $\begin{array}{c}1.452 \\
(13.38)\end{array}$ & $\begin{array}{l}(0.040) \\
(-0.20)\end{array}$ & $\begin{array}{l}(0.122) \\
(-1.67)\end{array}$ & 0.914 & 0.055 \\
\hline Sri Lanka & $\begin{array}{l}(0.087) \\
(-1.07)\end{array}$ & $\begin{array}{l}1.618 \\
(2.112)\end{array}$ & $\begin{array}{c}0.514 \\
(1.249)\end{array}$ & $\begin{array}{l}(0.000) \\
(-0.00)\end{array}$ & 0.256 & 0.077 \\
\hline Mauritius & $\begin{array}{c}0.006 \\
(0.183)\end{array}$ & $\begin{array}{c}0.619 \\
(3.175)\end{array}$ & $\begin{array}{c}0.240 \\
(1.080)\end{array}$ & $\begin{array}{l}-0.097 \\
(-0.47)\end{array}$ & 0.300 & 0.061 \\
\hline Mexico & $\begin{array}{l}-0.010 \\
(-0.17)\end{array}$ & $\begin{array}{c}0.842 \\
(7.558)\end{array}$ & $\begin{array}{c}0.253 \\
(0.616)\end{array}$ & $\begin{array}{c}0.039 \\
(0.333)\end{array}$ & 0.838 & 0.111 \\
\hline Morocco & $\begin{array}{l}-0.087 \\
(-2.34)\end{array}$ & $\begin{array}{c}0.400 \\
(1.366)\end{array}$ & $\begin{array}{c}0.737 \\
(2.637)\end{array}$ & $\begin{array}{c}0.186 \\
(-0.770)\end{array}$ & 0.224 & 0.066 \\
\hline Pakistan & $\begin{array}{c}0.055 \\
(1.257)\end{array}$ & $\begin{array}{c}0.449 \\
(1.270)\end{array}$ & $\begin{array}{c}0.222 \\
(0.858)\end{array}$ & $\begin{array}{c}-0.208 \\
(-0.820)\end{array}$ & -0.027 & 0.074 \\
\hline Poland & $\begin{array}{c}0.071 \\
(0.925)\end{array}$ & $\begin{array}{c}0.429 \\
(2.950)\end{array}$ & $\begin{array}{c}0.154 \\
(0.192)\end{array}$ & $\begin{array}{c}0.013 \\
(0.042)\end{array}$ & 0.628 & 0.160 \\
\hline Singapore & $\begin{array}{c}0.019 \\
(0.718)\end{array}$ & $\begin{array}{l}-0.193 \\
(-0.60)\end{array}$ & $\begin{array}{c}-0.235 \\
(-1.021)\end{array}$ & $\begin{array}{c}-0.133 \\
(-0.502)\end{array}$ & -0.120 & 0.046 \\
\hline South Africa & $\begin{array}{c}0.029 \\
(0.758)\end{array}$ & $\begin{array}{c}0.324 \\
(2.810)\end{array}$ & $\begin{array}{l}-0.006 \\
(-0.03)\end{array}$ & $\begin{array}{c}0.432 \\
(2.497)\end{array}$ & 0.470 & 0.030 \\
\hline Syria & $\begin{array}{l}-0.005 \\
(-0.04)\end{array}$ & $\begin{array}{c}0.168 \\
(1.421)\end{array}$ & $\begin{array}{c}0.234 \\
(0.347)\end{array}$ & $\begin{array}{c}-0.265 \\
(-0.861)\end{array}$ & 0.036 & 0.119 \\
\hline Taiwan & $\begin{array}{l}-0.023 \\
(-0.87)\end{array}$ & $\begin{array}{c}1.146 \\
(1.699)\end{array}$ & $\begin{array}{c}0.151 \\
(0.757)\end{array}$ & $\begin{array}{c}0.015 \\
(0.051)\end{array}$ & 0.051 & 0.055 \\
\hline Thailand & $\begin{array}{c}0.042 \\
(1.348)\end{array}$ & $\begin{array}{c}0.846 \\
(5.191)\end{array}$ & $\begin{array}{c}0.103 \\
(0.489)\end{array}$ & $\begin{array}{c}-0.307 \\
(-1.921)\end{array}$ & 0.601 & 0.057 \\
\hline Turkey & $\begin{array}{l}-0.041 \\
(-0.61)\end{array}$ & $\begin{array}{c}0.889 \\
(8.509)\end{array}$ & $\begin{array}{c}0.384 \\
(1.087)\end{array}$ & $\begin{array}{c}0.109 \\
(1.099)\end{array}$ & 0.905 & 0.072 \\
\hline Venezuela & $\begin{array}{c}0.047 \\
(0.928) \\
\end{array}$ & $\begin{array}{c}0.748 \\
(9.125) \\
\end{array}$ & $\begin{array}{l}-0.045 \\
(-0.14) \\
\end{array}$ & $\begin{array}{c}0.147 \\
(1.415) \\
\end{array}$ & 0.829 & 0.087 \\
\hline
\end{tabular}

Dependent variable: $\Delta \mathrm{P}_{\mathrm{M}, \mathrm{t}} \mathrm{t}$-statistics in parentheses. All variables in logs. 
Table 3: Pass-Through Estimates for Industrial Countries Using the Autoregressive Distributed Lag (ADL) Approach (US dollars, 1984-2003)

\begin{tabular}{|c|c|c|c|c|c|c|}
\hline Country & Constant & $\Delta E_{t}$ & $\Delta P_{t}^{*}$ & $\Delta P_{M, t-1}$ & Adj. $R^{2}$ & St. Error \\
\hline Australia & $\begin{array}{l}-0.012 \\
(-0.85)\end{array}$ & $\begin{array}{c}0.529 \\
(6.507)\end{array}$ & $\begin{array}{c}0.183 \\
(1.836)\end{array}$ & $\begin{array}{c}0.170 \\
(1.440)\end{array}$ & 0.716 & 0.028 \\
\hline Belgium-Luxemburg & $\begin{array}{c}-0.007 \\
(-0.190)\end{array}$ & $\begin{array}{c}0.365 \\
(3.414)\end{array}$ & $\begin{array}{c}0.094 \\
(0.399)\end{array}$ & $\begin{array}{c}0.080 \\
(0.345)\end{array}$ & 0.476 & 0.042 \\
\hline Canada & $\begin{array}{c}-0.007 \\
(-0.660)\end{array}$ & $\begin{array}{c}0.472 \\
(4.294)\end{array}$ & $\begin{array}{c}0.124 \\
(1.777)\end{array}$ & $\begin{array}{c}0.113 \\
(0.515)\end{array}$ & 0.615 & 0.020 \\
\hline Denmark & $\begin{array}{c}0.006 \\
(0.478)\end{array}$ & $\begin{array}{c}0.267 \\
(4.499)\end{array}$ & $\begin{array}{l}-0.010 \\
(-0.10)\end{array}$ & $\begin{array}{c}0.100 \\
(0.592)\end{array}$ & 0.538 & 0.027 \\
\hline Finland & $\begin{array}{l}-0.031 \\
(-1.436)\end{array}$ & $\begin{array}{c}0.400 \\
(4.475)\end{array}$ & $\begin{array}{c}0.319 \\
(1.961)\end{array}$ & $\begin{array}{c}-0.312 \\
(-1.737)\end{array}$ & 0.522 & 0.044 \\
\hline Germany & $\begin{array}{l}-0.029 \\
(-1.324)\end{array}$ & $\begin{array}{c}0.410 \\
(4.242)\end{array}$ & $\begin{array}{c}0.199 \\
(1.203)\end{array}$ & $\begin{array}{c}-0.102 \\
(-0.580)\end{array}$ & 0.477 & 0.046 \\
\hline Greece & $\begin{array}{c}-0.007 \\
(-0.247)\end{array}$ & $\begin{array}{c}0.013 \\
(0.085)\end{array}$ & $\begin{array}{c}0.432 \\
(1.672)\end{array}$ & $\begin{array}{c}0.321 \\
(1.398)\end{array}$ & 0.367 & 0.057 \\
\hline Iceland & $\begin{array}{l}-0.015 \\
(-0.39)\end{array}$ & $\begin{array}{c}0.572 \\
(4.351)\end{array}$ & $\begin{array}{c}0.151 \\
(0.616)\end{array}$ & $\begin{array}{c}0.511 \\
(3.425)\end{array}$ & 0.721 & 0.043 \\
\hline Ireland & $\begin{array}{c}-0.015 \\
(-1.063)\end{array}$ & $\begin{array}{c}0.464 \\
(6.318)\end{array}$ & $\begin{array}{c}0.228 \\
(2.068)\end{array}$ & $\begin{array}{c}-0.060 \\
(-0.412)\end{array}$ & 0.388 & 0.049 \\
\hline Italy & $\begin{array}{c}0.011 \\
(0.414)\end{array}$ & $\begin{array}{c}0.489 \\
(4.347)\end{array}$ & $\begin{array}{c}0.088 \\
(0.464)\end{array}$ & $\begin{array}{c}-0.096 \\
(-0.560)\end{array}$ & 0.495 & 0.077 \\
\hline Japan & $\begin{array}{l}-0.029 \\
(-0.99)\end{array}$ & $\begin{array}{c}0.964 \\
(6.906)\end{array}$ & $\begin{array}{c}0.179 \\
(0.799)\end{array}$ & $\begin{array}{c}-0.248 \\
(-1.760)\end{array}$ & 0.735 & 0.062 \\
\hline Netherlands & $\begin{array}{c}-0.005 \\
(-0.238)\end{array}$ & $\begin{array}{c}0.466 \\
(4.873)\end{array}$ & $\begin{array}{c}0.051 \\
(0.312)\end{array}$ & $\begin{array}{c}-0.042 \\
(-0.258)\end{array}$ & 0.557 & 0.046 \\
\hline New Zealand & $\begin{array}{c}0.000 \\
(-0.66)\end{array}$ & $\begin{array}{c}2.000 \\
(40001)\end{array}$ & $\begin{array}{c}0.000 \\
(0.560)\end{array}$ & $\begin{array}{c}0.000 \\
(1.524)\end{array}$ & 1.000 & 0.000 \\
\hline Norway & $\begin{array}{c}-0.016 \\
(-0.593)\end{array}$ & $\begin{array}{c}-0.170 \\
(-0.658)\end{array}$ & $\begin{array}{c}0.247 \\
(1.141)\end{array}$ & $\begin{array}{c}0.371 \\
(1.482)\end{array}$ & 0.176 & 0.056 \\
\hline Portugal & $\begin{array}{c}-0.052 \\
(-2.263)\end{array}$ & $\begin{array}{c}0.278 \\
(2.459)\end{array}$ & $\begin{array}{c}0.509 \\
(2.835)\end{array}$ & $\begin{array}{c}-0.475 \\
(-2.343)\end{array}$ & 0.438 & 0.045 \\
\hline Spain & $\begin{array}{c}-0.015 \\
(-0.553)\end{array}$ & $\begin{array}{c}0.444 \\
(3.508)\end{array}$ & $\begin{array}{c}0.083 \\
(0.410)\end{array}$ & $\begin{array}{l}-0.115 \\
(-0.587)\end{array}$ & 0.355 & 0.058 \\
\hline Sweden & $\begin{array}{l}-0.001 \\
(-0.040)\end{array}$ & $\begin{array}{c}0.310 \\
(4.138)\end{array}$ & $\begin{array}{c}0.197 \\
(1.508)\end{array}$ & $\begin{array}{l}-0.048 \\
(-0.26)\end{array}$ & 0.481 & 0.037 \\
\hline UK & $\begin{array}{l}-0.031 \\
(-2.00)\end{array}$ & $\begin{array}{c}0.314 \\
(3.143)\end{array}$ & $\begin{array}{c}0.356 \\
(2.842)\end{array}$ & $\begin{array}{l}-0.064 \\
(-0.31)\end{array}$ & 0.478 & 0.030 \\
\hline
\end{tabular}

Dependent variable: $\Delta \mathrm{P}_{\mathrm{M}, \mathrm{t}} \mathrm{t}$-statistics in parentheses. All variables in logs. 
Table 4: Pass-Through Estimates for Developing Countries Using the Error Correction Approach (US dollars, 1984-2003)

\begin{tabular}{|c|c|c|c|c|c|c|c|c|}
\hline Country & Constant & $\Delta E_{t}$ & $\Delta P_{t}^{*}$ & $E_{t-1}$ & $P_{t-1}^{*}$ & $\varepsilon_{t-1}$ & Adj. $R^{2}$ & St. Erro1 \\
\hline Argentina & $\begin{array}{c}0.262 \\
(0.325)\end{array}$ & $\begin{array}{c}1.000 \\
(107.198)\end{array}$ & $\begin{array}{c}0.390 \\
(1.698)\end{array}$ & $\begin{array}{c}-0.013 \\
(-1.683)\end{array}$ & $\begin{array}{c}-0.063 \\
(-0.365)\end{array}$ & $\begin{array}{c}-0.111 \\
(-0.747)\end{array}$ & 0.999 & 0.029 \\
\hline Brazil & $\begin{array}{c}2.901 \\
(1.380)\end{array}$ & $\begin{array}{c}0.949 \\
(14.136)\end{array}$ & $\begin{array}{c}0.782 \\
(0.547)\end{array}$ & $\begin{array}{c}0.037 \\
(0.950)\end{array}$ & $\begin{array}{c}-0.649 \\
(-1.417)\end{array}$ & $\begin{array}{l}-0.448 \\
(-1.881)\end{array}$ & 0.991 & 0.113 \\
\hline China & $\begin{array}{l}2.518 \\
(2.0250\end{array}$ & $\begin{array}{c}1.984 \\
(5.270)\end{array}$ & $\begin{array}{c}-0.499 \\
(-0.772)\end{array}$ & $\begin{array}{c}0.580 \\
(1.520)\end{array}$ & $\begin{array}{c}-0.825 \\
(-2.070)\end{array}$ & $\begin{array}{c}-0.639 \\
(-2.137)\end{array}$ & 0.851 & 90.000 \\
\hline Chile & $\begin{array}{c}6.091 \\
(3.740)\end{array}$ & $\begin{array}{c}0.699 \\
(4.825)\end{array}$ & $\begin{array}{c}0.084 \\
(0.479)\end{array}$ & $\begin{array}{c}-0.473 \\
(-3.729)\end{array}$ & $\begin{array}{c}-0.681 \\
(-3.062)\end{array}$ & $\begin{array}{c}-0.953 \\
(-3.636)\end{array}$ & 0.966 & 0.020 \\
\hline Colombia & $\begin{array}{c}1.298 \\
(0.974)\end{array}$ & $\begin{array}{c}0.455 \\
(2.175)\end{array}$ & $\begin{array}{c}0.054 \\
(0.222)\end{array}$ & $\begin{array}{c}-0.074 \\
(-0.879)\end{array}$ & $\begin{array}{c}-0.151 \\
(-0.797)\end{array}$ & $\begin{array}{c}-0.186 \\
(-0.732)\end{array}$ & 0.713 & 0.039 \\
\hline Hong Kong & $\begin{array}{c}1.468 \\
(0.234)\end{array}$ & $\begin{array}{c}7.315 \\
(1.878)\end{array}$ & $\begin{array}{c}0.292 \\
(2.097)\end{array}$ & $\begin{array}{l}-0.490 \\
(-0.175)\end{array}$ & $\begin{array}{c}-0.109 \\
(-0.717)\end{array}$ & $\begin{array}{c}-0.100 \\
(-0.623)\end{array}$ & 0.432 & 0.024 \\
\hline Hungary & $\begin{array}{c}4.944 \\
(4.229)\end{array}$ & $\begin{array}{c}0.435 \\
(2.674)\end{array}$ & $\begin{array}{c}-0.466 \\
(-1.392)\end{array}$ & $\begin{array}{c}-0.531 \\
(-4.0140\end{array}$ & $\begin{array}{c}-0.413 \\
(-2.589)\end{array}$ & $\begin{array}{c}-0.931 \\
(-4.031)\end{array}$ & 0.745 & 0.050 \\
\hline India & $\begin{array}{c}3.990 \\
(2.668)\end{array}$ & $\begin{array}{c}0.938 \\
(1.762)\end{array}$ & $\begin{array}{c}0.243 \\
(0.528)\end{array}$ & $\begin{array}{l}-0.455 \\
(-1.100)\end{array}$ & $\begin{array}{c}-0.502 \\
(-1.216)\end{array}$ & $\begin{array}{c}-0.727 \\
(-2.418)\end{array}$ & 0.210 & 0.094 \\
\hline Jordan & $\begin{array}{c}2.344 \\
(1.223)\end{array}$ & $\begin{array}{c}0.946 \\
(5.534)\end{array}$ & $\begin{array}{c}-0.005 \\
(-0.008)\end{array}$ & $\begin{array}{c}-0.034 \\
(-0.172)\end{array}$ & $\begin{array}{c}-0.506 \\
(-1.258)\end{array}$ & $\begin{array}{c}-0.575 \\
(-1.632)\end{array}$ & 0.752 & 0.067 \\
\hline Kenya & $\begin{array}{c}4.914 \\
(3.607)\end{array}$ & $\begin{array}{c}0.671 \\
(6.191)\end{array}$ & $\begin{array}{c}-0.045 \\
(-0.166)\end{array}$ & $\begin{array}{l}-0.451 \\
(-2.968)\end{array}$ & $\begin{array}{c}-0.646 \\
(-2.746)\end{array}$ & $\begin{array}{l}-1.019 \\
(-3.581)\end{array}$ & 0.828 & 0.051 \\
\hline Korea & $\begin{array}{c}0.606 \\
(0.834)\end{array}$ & $\begin{array}{c}1.419 \\
(11.943)\end{array}$ & $\begin{array}{c}-0.142 \\
(-0.447)\end{array}$ & $\begin{array}{c}0.271 \\
(1.741)\end{array}$ & $\begin{array}{c}-0.550 \\
(-2.523)\end{array}$ & $\begin{array}{c}-0.626 \\
(-2.537)\end{array}$ & 0.922 & 0.051 \\
\hline Mauritius & $\begin{array}{c}2.936 \\
(2.236)\end{array}$ & $\begin{array}{c}0.640 \\
(3.523)\end{array}$ & $\begin{array}{c}0.533 \\
(1.980)\end{array}$ & $\begin{array}{c}-0.215 \\
(-1.332)\end{array}$ & $\begin{array}{c}-0.482 \\
(-2.389)\end{array}$ & $\begin{array}{l}-0.650 \\
(-2.472)\end{array}$ & 0.507 & 0.051 \\
\hline Mexico & $\begin{array}{c}3.435 \\
(2.801)\end{array}$ & $\begin{array}{c}0.847 \\
(6.799)\end{array}$ & $\begin{array}{c}-0.041 \\
(-0.0950\end{array}$ & $\begin{array}{l}-0.075 \\
(-0.978)\end{array}$ & $\begin{array}{c}-0.761 \\
(-2.909)\end{array}$ & $\begin{array}{l}-0.885 \\
(-2.863)\end{array}$ & 0.909 & 0.082 \\
\hline Morocco & $\begin{array}{c}3.043 \\
(1.966)\end{array}$ & $\begin{array}{c}0.330 \\
(1.264)\end{array}$ & $\begin{array}{c}0.782 \\
(2.573)\end{array}$ & $\begin{array}{c}-0.575 \\
(-1.554)\end{array}$ & $\begin{array}{c}-0.375 \\
(-2.274)\end{array}$ & $\begin{array}{c}-0.448 \\
(-2.330)\end{array}$ & 0.428 & 0.058 \\
\hline Pakistan & $\begin{array}{c}2.608 \\
(2.286)\end{array}$ & $\begin{array}{c}0.601 \\
(1.531)\end{array}$ & $\begin{array}{c}0.483 \\
(1.330)\end{array}$ & $\begin{array}{l}-0.008 \\
(-0.043)\end{array}$ & $\begin{array}{c}-0.562 \\
(-2.165)\end{array}$ & $\begin{array}{l}-0.681 \\
(-2.434)\end{array}$ & 0.159 & 0.066 \\
\hline Poland & $\begin{array}{c}9.991 \\
(3.260)\end{array}$ & $\begin{array}{c}1.185 \\
(4.691)\end{array}$ & $\begin{array}{c}-1.796 \\
(-1.795)\end{array}$ & $\begin{array}{c}-0.974 \\
(-3.210)\end{array}$ & $\begin{array}{c}-1.828 \\
(-3.164)\end{array}$ & $\begin{array}{l}-2.485 \\
(-3.274)\end{array}$ & 0.812 & 0.110 \\
\hline Singapore & $\begin{array}{c}3.545 \\
(3.139)\end{array}$ & $\begin{array}{c}-0.051 \\
(-0.210)\end{array}$ & $\begin{array}{c}0.068 \\
(0.287)\end{array}$ & $\begin{array}{l}-0.451 \\
(-2.196)\end{array}$ & $\begin{array}{c}-0.720 \\
(-3.189)\end{array}$ & $\begin{array}{l}-0.736 \\
(-3.371)\end{array}$ & 0.366 & 0.034 \\
\hline South Africa & $\begin{array}{c}1.780 \\
(3.704)\end{array}$ & $\begin{array}{c}0.393 \\
(7.293)\end{array}$ & $\begin{array}{c}0.156 \\
(1.203)\end{array}$ & $\begin{array}{c}-0.017 \\
(-0.303)\end{array}$ & $\begin{array}{c}-0.365 \\
(-4.076)\end{array}$ & $\begin{array}{c}-0.404 \\
(-3.284)\end{array}$ & 0.810 & 0.023 \\
\hline Sri Lanka & $\begin{array}{c}2.762 \\
(1.520)\end{array}$ & $\begin{array}{l}1.714 \\
(2.617)\end{array}$ & $\begin{array}{c}0.922 \\
(1.322)\end{array}$ & $\begin{array}{c}-0.654 \\
(-0.505)\end{array}$ & $\begin{array}{c}-0.041 \\
(-0.049)\end{array}$ & $\begin{array}{c}-0.415 \\
(-0.926)\end{array}$ & 0.460 & 0.063 \\
\hline Syria & $\begin{array}{c}7.997 \\
(3.097)\end{array}$ & $\begin{array}{c}0.260 \\
(2.312)\end{array}$ & $\begin{array}{c}-0.573 \\
(-0.785)\end{array}$ & $\begin{array}{c}-1.024 \\
(-3.204)\end{array}$ & $\begin{array}{c}-1.189 \\
(-2.944)\end{array}$ & $\begin{array}{l}-1.300 \\
(-3.160)\end{array}$ & 0.464 & 0.095 \\
\hline Taiwan & $\begin{array}{c}0.331 \\
(0.293)\end{array}$ & $\begin{array}{c}0.223 \\
(1.005)\end{array}$ & $\begin{array}{c}0.520 \\
(1.535)\end{array}$ & $\begin{array}{c}-0.084 \\
(-0.407)\end{array}$ & $\begin{array}{c}-0.208 \\
(-0.708)\end{array}$ & $\begin{array}{l}-0.260 \\
(-0.967)\end{array}$ & 0.396 & 0.043 \\
\hline Thailand & $\begin{array}{c}2.973 \\
(2.817)\end{array}$ & $\begin{array}{c}0.815 \\
(4.463)\end{array}$ & $\begin{array}{c}-0.003 \\
(-0.009)\end{array}$ & $\begin{array}{c}-0.203 \\
(-1.867)\end{array}$ & $\begin{array}{c}-0.477 \\
(-2.396)\end{array}$ & $\begin{array}{c}-0.687 \\
(-2.534)\end{array}$ & 0.636 & 0.053 \\
\hline Turkey & $\begin{array}{c}0.737 \\
(0.401)\end{array}$ & $\begin{array}{c}0.826 \\
(7.926)\end{array}$ & $\begin{array}{l}1.338 \\
(2.127)\end{array}$ & $\begin{array}{c}-0.024 \\
(-0.539)\end{array}$ & $\begin{array}{c}-0.084 \\
(-0.250)\end{array}$ & $\begin{array}{c}-0.362 \\
(-0.988)\end{array}$ & 0.943 & 0.055 \\
\hline Venezuela & $\begin{array}{c}0.638 \\
(0.377)\end{array}$ & $\begin{array}{c}0.707 \\
(5.954)\end{array}$ & $\begin{array}{l}-0.272 \\
(-0.405)\end{array}$ & $\begin{array}{l}-0.117 \\
(-1.216)\end{array}$ & $\begin{array}{c}0.049 \\
(0.108)\end{array}$ & $\begin{array}{c}-0.219 \\
(-0.688)\end{array}$ & 0.830 & 0.086 \\
\hline
\end{tabular}

Dependent variable: $\Delta \mathrm{P}_{\mathrm{M}, \mathrm{t}}$ t-statistics in parentheses. All variables in logs. 
Table 5: Pass-Through Estimates for Industrial Countries Using the Error Correction Approach (US dollars, 1984-2003)

\begin{tabular}{|c|c|c|c|c|c|c|c|c|}
\hline Country & Constant & $\Delta E_{t}$ & $\Delta P_{t}^{*}$ & $E_{t-1}$ & $P *_{t-1}$ & $\varepsilon_{t-1}$ & Adj. $R^{2}$ & St. Error \\
\hline Australia & $\begin{array}{c}1.281 \\
(2.812)\end{array}$ & $\begin{array}{c}0.532 \\
(6.699)\end{array}$ & $\begin{array}{c}0.220 \\
(1.860)\end{array}$ & $\begin{array}{c}-0.074 \\
(-0.564)\end{array}$ & $\begin{array}{c}-0.272 \\
(-1.935)\end{array}$ & $\begin{array}{c}-0.284 \\
(-1.708)\end{array}$ & 0.890 & 0.021 \\
\hline Belgium-Luxemburg & $\begin{array}{c}3.843 \\
(1.764)\end{array}$ & $\begin{array}{c}0.361 \\
(3.049)\end{array}$ & $\begin{array}{c}0.072 \\
(0.323)\end{array}$ & $\begin{array}{c}-0.412 \\
(-1.802)\end{array}$ & $\begin{array}{c}-0.533 \\
(-1.695)\end{array}$ & $\begin{array}{c}-0.540 \\
(-1.659)\end{array}$ & 0.558 & 0.037 \\
\hline Canada & $\begin{array}{c}2.616 \\
(2.508)\end{array}$ & $\begin{array}{c}0.502 \\
(5.832)\end{array}$ & $\begin{array}{c}0.200 \\
(1.926)\end{array}$ & $\begin{array}{c}-0.232 \\
(-1.710)\end{array}$ & $\begin{array}{c}-0.551 \\
(-2.537)\end{array}$ & $\begin{array}{c}-0.611 \\
(-2.569)\end{array}$ & 0.737 & 0.016 \\
\hline Denmark & $\begin{array}{c}2.986 \\
(1.966)\end{array}$ & $\begin{array}{c}0.262 \\
(3.917)\end{array}$ & $\begin{array}{c}-0.052 \\
(-0.361)\end{array}$ & $\begin{array}{c}-0.359 \\
(-1.901)\end{array}$ & $\begin{array}{c}-0.485 \\
(-1.965)\end{array}$ & $\begin{array}{c}-0.501 \\
(-1.980)\end{array}$ & 0.591 & 0.025 \\
\hline Finland & $\begin{array}{c}2.827 \\
(2.648)\end{array}$ & $\begin{array}{c}0.360 \\
(3.877)\end{array}$ & $\begin{array}{c}0.404 \\
(2.090)\end{array}$ & $\begin{array}{c}-0.392 \\
(-2.699)\end{array}$ & $\begin{array}{c}-0.469 \\
(-2.561)\end{array}$ & $\begin{array}{c}-0.527 \\
(-2.671)\end{array}$ & 0.614 & 0.039 \\
\hline Germany & $\begin{array}{c}3.034 \\
(2.851)\end{array}$ & $\begin{array}{c}0.409 \\
(4.238)\end{array}$ & $\begin{array}{c}0.281 \\
(1.296)\end{array}$ & $\begin{array}{c}-0.453 \\
(-2.592)\end{array}$ & $\begin{array}{c}-0.560 \\
(-2.884)\end{array}$ & $\begin{array}{c}-0.581 \\
(-2.901)\end{array}$ & 0.638 & 0.038 \\
\hline Greece & $\begin{array}{c}2.532 \\
(1.364)\end{array}$ & $\begin{array}{c}-0.001 \\
(-0.008)\end{array}$ & $\begin{array}{c}0.542 \\
(1.839)\end{array}$ & $\begin{array}{c}-0.331 \\
(-0.952)\end{array}$ & $\begin{array}{c}-0.131 \\
(-1.568)\end{array}$ & $\begin{array}{c}-0.273 \\
(-1.570)\end{array}$ & 0.652 & 0.045 \\
\hline Iceland & $\begin{array}{c}0.618 \\
(0.895)\end{array}$ & $\begin{array}{c}0.592 \\
(3.487)\end{array}$ & $\begin{array}{c}0.176 \\
(0.496)\end{array}$ & $\begin{array}{c}0.132 \\
(0.547)\end{array}$ & $\begin{array}{c}-0.263 \\
(-1.662)\end{array}$ & $\begin{array}{c}-0.211 \\
(-1.301)\end{array}$ & 0.799 & 0.042 \\
\hline Ireland & $\begin{array}{c}2.286 \\
(2.550)\end{array}$ & $\begin{array}{c}0.439 \\
(5.721)\end{array}$ & $\begin{array}{c}0.210 \\
(1.472)\end{array}$ & $\begin{array}{c}-0.439 \\
(-2.368)\end{array}$ & $\begin{array}{c}-0.524 \\
(-2.565)\end{array}$ & $\begin{array}{c}-0.570 \\
(-2.528)\end{array}$ & 0.774 & 0.026 \\
\hline Italy & $\begin{array}{c}5.194 \\
(1.889)\end{array}$ & $\begin{array}{c}0.426 \\
(3.524)\end{array}$ & $\begin{array}{c}0.132 \\
(0.500)\end{array}$ & $\begin{array}{c}-0.347 \\
(-1.659)\end{array}$ & $\begin{array}{c}-0.556 \\
(-2.010)\end{array}$ & $\begin{array}{c}-0.654 \\
(-2.070)\end{array}$ & 0.586 & 0.049 \\
\hline Japan & $\begin{array}{c}4.730 \\
(3.955)\end{array}$ & $\begin{array}{c}0.905 \\
(6.959)\end{array}$ & $\begin{array}{c}0.309 \\
(1.120)\end{array}$ & $\begin{array}{c}-0.241 \\
(-2.489)\end{array}$ & $\begin{array}{c}-0.794 \\
(-3.593)\end{array}$ & $\begin{array}{c}-0.782 \\
(-3.490)\end{array}$ & 0.849 & 0.046 \\
\hline Netherlands & $\begin{array}{c}3.348 \\
(2.727)\end{array}$ & $\begin{array}{c}0.437 \\
(4.532)\end{array}$ & $\begin{array}{c}0.137 \\
(0.624)\end{array}$ & $\begin{array}{c}-0.433 \\
(-2.564)\end{array}$ & $\begin{array}{c}-0.654 \\
(-2.724)\end{array}$ & $\begin{array}{c}-0.649 \\
(-2.724)\end{array}$ & 0.681 & 0.038 \\
\hline New Zealand & N/A & N/A & N/A & N/A & N/A & N/A & N/A & N/A \\
\hline Norway & $\begin{array}{c}2.128 \\
(1.782)\end{array}$ & $\begin{array}{c}-0.190 \\
(-0.829)\end{array}$ & $\begin{array}{c}0.402 \\
(1.604)\end{array}$ & $\begin{array}{c}-0.364 \\
(-1.009)\end{array}$ & $\begin{array}{c}-0.276 \\
(-2.783)\end{array}$ & $\begin{array}{c}-0.287 \\
(-2.126)\end{array}$ & 0.492 & 0.043 \\
\hline Portugal & $\begin{array}{c}8.455 \\
(5.407)\end{array}$ & $\begin{array}{c}0.188 \\
(2.105)\end{array}$ & $\begin{array}{c}0.660 \\
(3.575)\end{array}$ & $\begin{array}{c}-1.041 \\
(-5.106)\end{array}$ & $\begin{array}{c}-0.661 \\
(-5.396)\end{array}$ & $\begin{array}{c}-0.766 \\
(-5.361)\end{array}$ & 0.754 & 0.030 \\
\hline Spain & $\begin{array}{c}4.476 \\
(2.308)\end{array}$ & $\begin{array}{c}0.425 \\
(3.587)\end{array}$ & $\begin{array}{c}0.212 \\
(0.780)\end{array}$ & $\begin{array}{c}-0.330 \\
(-2.037)\end{array}$ & $\begin{array}{c}-0.607 \\
(-2.330)\end{array}$ & $\begin{array}{c}-0.615 \\
(-2.476)\end{array}$ & 0.574 & 0.046 \\
\hline Sweden & $\begin{array}{c}3.378 \\
(2.324)\end{array}$ & $\begin{array}{c}0.274 \\
(3.601)\end{array}$ & $\begin{array}{c}0.331 \\
(2.153)\end{array}$ & $\begin{array}{c}-0.422 \\
(-2.082)\end{array}$ & $\begin{array}{c}-0.531 \\
(-2.395)\end{array}$ & $\begin{array}{c}-0.652 \\
(-2.449)\end{array}$ & 0.632 & 0.030 \\
\hline UK & $\begin{array}{c}0.935 \\
(1.800)\end{array}$ & $\begin{array}{c}0.364 \\
(3.429)\end{array}$ & $\begin{array}{c}0.442 \\
(3.158)\end{array}$ & $\begin{array}{c}-0.124 \\
(-0.837)\end{array}$ & $\begin{array}{c}-0.219 \\
(-1.785)\end{array}$ & $\begin{array}{c}-0.251 \\
(-1.792)\end{array}$ & 0.569 & 0.027 \\
\hline
\end{tabular}

Dependent variable: $\Delta \mathrm{P}_{\mathrm{M}, \mathrm{t}} \mathrm{t}$-statistics in parentheses. All variables in logs. $\mathrm{N} / \mathrm{A}$ indicates that estimates are not available due to singularity issues. 
Table 6: Panel Data Pass-Through Estimates for Industrial and Developing Countries Using the Autoregressive Distributed Lag (ADL) Approach with Fixed Effects (1984-2003 and Sub-Periods)

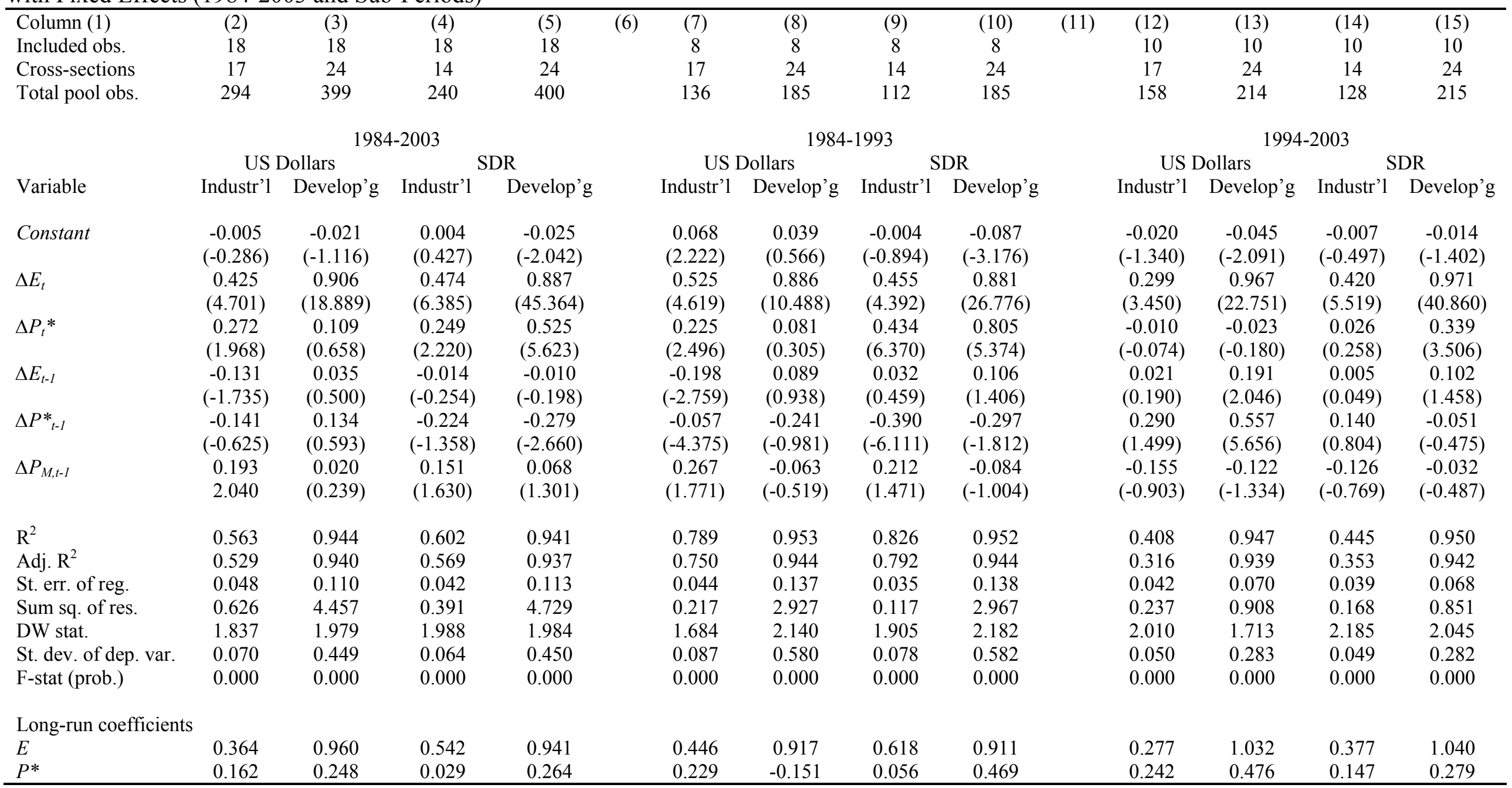

Dependent variable: $\Delta \mathrm{P}_{\mathrm{M}, \mathrm{t}}$ t-statistics (based on White cross-section standard errors) in parentheses. All variables in logs. New Zealand, China, and Hong Kong excluded for dollar estimates. US, UK, Germany, New Zealand, and Japan excluded for SDR estimates. Fixed effects coefficients available from the author on request. 
Table 7: Panel Data Pass-Through Estimates for Industrial and Developing Countries Using the Error Correction Approach with Fixed Effects (19842003 and Sub-Periods)

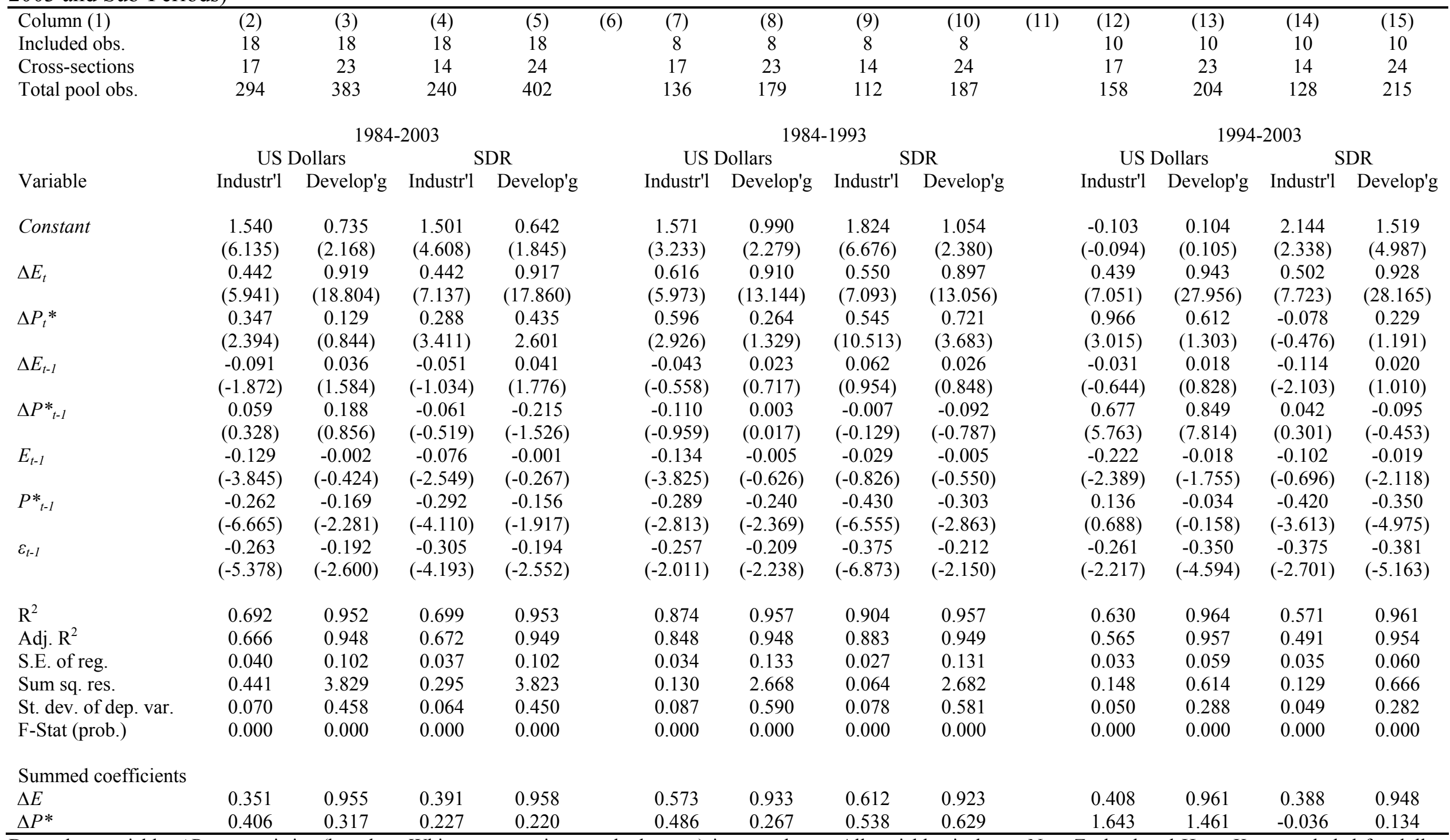

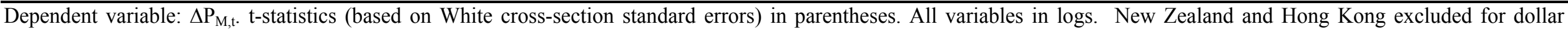
estimates. US, UK, Germany, New Zealand, and Japan excluded for SDR estimates. Fixed effects coefficients available from the author on request. 


\section{Notes}

*The author would like to acknowledge helpful comments on previous drafts by Robert Feinberg, Peter Skott, and an anonymous referee. The usual disclaimers apply.

${ }^{\mathrm{i}}$ Two recent studies, Feinberg (2000) and Frankel et al. (2005), are relatively rare exceptions.

${ }^{\mathrm{ii}}$ The latter is mainly due to dearth of available data.

${ }^{i i i}$ See, for example, Devereux \& Engel (2000) and Gagnon \& Ihrig (2001).

${ }^{\text {iv }}$ See Lizondo \& Montiel (1989) for a comprehensive analysis. A few recent studies have emphasised 'balance sheet' effects. See, for example, Céspedes et al. (2004). We, however, limit our focus to non-financial aspects.

${ }^{\mathrm{v}}$ In the presence of a trade deficit, the valuation effect of an exchange rate change will be greater on imports than on exports because of the greater initial volume of the former.

${ }^{\mathrm{vi}}$ See Menon (1996) for some supporting evidence.

${ }^{\text {vii }}$ See, for example, Faini et al. (1992) and Razmi \& Blecker (2005).

${ }^{\text {viii }}$ See Dornbusch (1987) for the theoretical underpinnings of this hypothesis.

${ }^{\mathrm{ix}}$ Some interesting support for this is provided by recent events in the wake of the depreciation of the US dollar. As Alan Greenspan noted in his testimony to the US Senate on February 162005 , 'Although the dollar has been declining since early 2002, exporters to the United States apparently have held dollar prices relatively steady to preserve their market share, effectively choosing to absorb the decline in the dollar by accepting a reduction in their profit margins.'

${ }^{\mathrm{x}}$ See Choudhri \& Hakura (2001) for some empirical support.

${ }^{x i}$ As measured by the variance of money supplies across countries.

${ }^{x i i}$ See Ho \& McCauley (2003) for evidence of higher inflation in developing countries over our sample period.

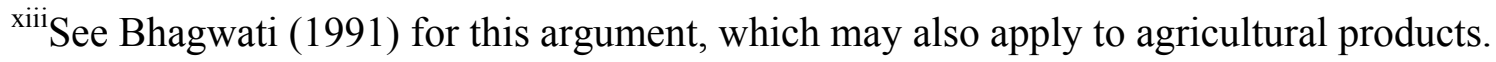

${ }^{\text {xiv }}$ These specifications are, of course, exceedingly simplified in that they assume complete and zero pass-through, respectively. Note, however, that more involved specifications that allow for intermediate degrees of pass-through would complicate the analysis without changing it qualitatively.

${ }^{\mathrm{xv}}$ This implies in particular that $P_{H}$ is the proper deflator to use for real income.

${ }^{\mathrm{xvi}}$ It is easily demonstrated that if trade is initially balanced,

$$
(d H / d e)(e / H)=-\left(\gamma / P_{H} H \Delta\right) P_{X} X^{D}<0
$$

${ }^{\text {xvii }}$ And even more so if there is an initial trade deficit.

${ }^{x v i i i}$ The developing country group includes Argentina, Brazil, China, Chile, Columbia, Hong Kong, Hungary, India, Jordan, Kenya, South Korea, Sri Lanka, Mauritius, Mexico, Morocco, Pakistan, Poland, Singapore, South Africa, Syria, Taiwan, Thailand, Turkey, and Venezuela, 
while the industrialised country group consists of Australia, Belgium-Luxembourg, Canada, Denmark, Finland, Germany, Greece, Iceland, Ireland, Italy, Japan, Netherlands, New Zealand, Norway, Portugal, Spain, Sweden, United Kingdom, and the United States.

${ }^{x i x}$ China is an exception in that import price data for it were not available from the IFS, and were obtained from the World Bank's World Development Indicators instead. This exception can be justified on the grounds of China's enormous importance in global markets.

${ }^{x x}$ See the symbol definitions immediately following equation (14) below. In a very small number of instances the variables were either found to be stationary or I(2).

${ }^{x x i}$ Considering that most of our time series are I(1), using first-differenced values also addresses the non-stationarity issue while emphasising the short-run signal.

${ }^{x x i i}$ The change in cost structure abroad, in turn, may be due to changes in input costs or due to other factors such as variable returns to scale or variable mark-up over costs.

${ }^{x x i i i}$ We use domestic CPI as a proxy for individual country domestic price of import-substitutes. Due to the greater weight given to tradable goods in its construction, the PPI offers a preferable alternative. However, data for this variable were not available for a number of countries. Note that the inclusion of the domestic price variable slightly alters the specification of our empirical model to:

$\Delta P_{M i, t}=\beta_{0 i}+\sum_{p=0}^{n} \beta_{1 i, p} \Delta E_{i, t-p}+\sum_{p=0}^{n} \beta_{2 i, p} \Delta P_{i, t-p}^{*}+\sum_{p=0}^{n} \beta_{3 i, p} \Delta P_{i, t-p}+\sum_{q=1}^{n} \beta_{4 i, q} \Delta P_{M i, t-q}+\sum_{p=0}^{n} \varepsilon_{i, t-p}$

where $P_{i}$ is the domestic price of import-substitutes in the $i^{\text {th }}$ country. See section 6.1 below.

${ }^{\mathrm{xxiv}}$ The inclusion of lagged regressors is designed to avoid assuming homogeneity in the presence of unknown long-run coefficients (Banerjee et al., 1993). Note that these are not present in our third approach where full pass-through is assumed in the long-run.

${ }^{\mathrm{xx}} \mathrm{This}$ is not surprising considering that our data has an annual frequency and the variables are specified in their first-differenced forms.

${ }^{\mathrm{xxvi}}$ Namely that the US currency does not vary relative to itself.

xxvii The corresponding median values are 0.618 and 0.228 , respectively. These and the median values reported below suggest that our averages are not driven by a few outliers.

xxviii The corresponding median values are 0.427 and 0.181 , respectively.

${ }^{\text {xxix }}$ The corresponding median values are 0.720 and 0.173 for developing countries, and 0.450 and 0.183 for industrial countries, respectively.

${ }^{\mathrm{xxx}}$ The Jarque-Bera test statistic has an asymptotic $\chi^{2}$ distribution with two degrees of freedom under the null hypothesis of normally distributed errors. The Breusch-Godfrey LM $n R^{2}$ test statistic ( $n$ being the number of observations in the sample) has an asymptotic $\chi^{2}(p)$ distribution under the null hypothesis of no serial correlation between the residuals up to the lag order $p$. The ARCH LM $n R^{2}$ test statistic has an asymptotic $\chi^{2}(q)$ distribution under the null hypothesis of no serial correlation between the residuals up to the lag order $q$. 
${ }^{\mathrm{xxxi}}$ The standardised cumulative recursive residual CUSUM test is based on the cumulative sum of the recursive residuals. The plots, although not presented here, can be provided by the author on request.

${ }^{x x x i i}$ The results of the regressions with the domestic CPI as an additional control variable are available from the author on request.

${ }^{\mathrm{xxxiii}}$ For most of the countries in our sample, these values lie between 5 and 20 percent.

${ }^{x x x i v}$ Ideally we would like to use weighted nominal exchange rate indices constructed separately for each country. IMF's International Finance Statistics reports such indices for many countries. However, this index is missing for a number of (mainly developing) countries in our sample. Moreover, considering that a bulk of non-US international transactions takes place in dollars, such indices are unlikely to accurately reflect the weight of the dollar (as opposed to the weight of each exporter) in international transactions.

${ }^{\mathrm{xxx}}$ The latter two, of course, have been replaced by the euro in recent years. The reader is referred to the IMF's website for further details about the construction of SDRs.

${ }^{\mathrm{xxxvi}}$ The results of the SDR regressions are available from the author on request.

${ }^{x x x v i i}$ Recall that these regressions are based on equation (15).

${ }^{x x x v i i i}$ Note that the test statistic for the error correction term does not have the standard distribution. The critical values for a sample consisting of 25 periods are $-2.99,-3.45$, and -4.22 at the 10,5 , and 1 percent levels of significance, respectively.

${ }^{\mathrm{xxxix}}$ The results are available from the author on request.

${ }^{\mathrm{xl}}$ See Baltagi (2001) for a discussion.

${ }^{x l i}$ We employed the Hadri panel unit root test which has a null hypothesis of no unit root in any of the series in the panel. The results, although not reported here, are available from the author on request.

${ }^{x l i i}$ Due to the extremely high (greater than 2) pass-through estimates for New Zealand and Hong Kong in the individual country regressions, these countries were excluded from the panels.

${ }^{x}$ liii Removing developing countries that were excluded from our calculation of averages of individual country estimates does not significantly change the contemporary coefficient, reducing it slightly to 0.897 .

${ }^{x l i v}$ Note that the long-run effect pass-through can be calculated by dividing the sum of the individual pass-through coefficients by one minus the coefficient on the lagged dependent variable. Since we are interested in short-run effects, however, the long-run effects are presented but not discussed in any detail.

${ }^{\mathrm{xlv}}$ The increase becomes particularly marked once we take into account time-specific effects (see below).

${ }^{x l v i}$ As a further sensitivity test, we re-ran the regressions without the lagged dependent variable as a regressor. The results were essentially unchanged.

${ }^{x l v i i}$ As well as the ones derived from the alternative error correction approach with long-run 
homogeneity imposed, and the regressions with domestic CPI added as a regressor (not reported but available on request).

${ }^{x l v i i i}$ With the exception of fiscal effects; see below.

${ }^{x}$ Iix In other words, while substitution effects may dampen the overall contractionary (income) effects of a nominal devaluation, the relative impact on the contractionary effects originating from industrialised and developing countries is ambiguous, and will depend on the respective elasticities of substitution in consumption and production. Moreover, such substitution effects, even though not entirely absent, are likely to be relatively weak in the short-run.

\section{References}

Baltagi, B. (2001) Econometric Analysis of Panel Data, (New York, John Wiley and Sons).

Banerjee, A., Dolado, J. G., \& Hendry, D. (1993) Co-integration, error correction, and the econometric analysis of non-stationary data, (Oxford, Oxford University Press).

Bhagwati, J. (1991) The pass-through puzzle: The missing prince from Hamlet, in: D. A. Irwin (Ed.) Political Economy and International Economics, (Cambridge, MIT Press).

Campa, J. M. \& Goldberg, L. S. (2005) Exchange Rate Pass-Through into Import Prices, Review of Economics and Statistics, 87(4), pp. 679-690.

Céspedes, L. J., Chang, R., \& Velasco, A. (2004) Balance sheets and exchange rate policy, American Economic Review, 94(4), pp. 1183-1193.

Chang, H.-J. (1998) Transnational corporations and strategic industrial policy. In R. KozulWright \& R. Rowthorn, editors, Transnational Corporations and the Global Economy, (England, Antony Rowe Ltd.)

Choudhri, E. \& Hakura, D. (2001) Exchange rate pass-through to domestic prices: Does the inflationary environment matter? Working Paper 01/194, International Monetary Fund, Washington, DC.

Devereux, M. \& Engel, C. (2000) Monetary policy in the open economy revisited: Price setting and exchange rate flexibility, Working Paper 7665, National Bureau of Economic Research, Cambridge, MA.

Devereux, M. \& Engel, C. (2001) Endogenous currency of price setting in a dynamic open economy model, Working Paper 8559, National Bureau of Economic Research, Cambridge.

Diaz-Alejandro, C. (1963) A note on the impact of devaluation and the redistributive effects, Journal of Political Economy, 71, pp. 577-80.

Dornbusch, R. (1987) Exchange rates and prices, American Economic Review, 77(1), pp. 93-106.

Faini, R., Clavijo, F., \& Senhadji-Semlali, A. (1992) The fallacy of composition argument: Is it relevant for LDCs manufactures' exports? European Economic Review, 36(4), pp. 865-82.

Feinberg, R. (2000) The role of international discipline in three developing economies: Exchange 
rate effects on domestic prices in Colombia, Korea, and Morocco, Review of International Economics, 8(1), pp 126-133.

Frankel, J., Parsley, D., \& Wei, S.-J. (2005) Slow passthrough around the world: A new import for developing countries? Working Paper 11199, National Bureau of Economic Research.

Gagnon, J. \& Ihrig, J. (2001) Monetary policy and exchange rate pass-through, International Finance Discussion Paper 704, Federal Reserve Board, Washington, DC.

Hirschman, A. O. (1949) Devaluation and the trade balance: a note, Review of Economics and Statistics, 31, pp. 50-3.

Ho, C. \& McCauley, R. (2003) Living with flexible exchange rates: Issues and recent experience in inflation targeting emerging market economies. Working Paper 130, Bank of International Settlements, Basel.

Hsiao, C. (2003) Analysis of Panel Data, (Cambridge, Cambridge University Press).

Krugman, P. \& Taylor, L. (1978) Contractionary effects of devaluation, Journal of International Economics, (8), pp. 445-56.

Lizondo, S. J. \& Montiel, P. J. (1989) Contractionary devaluation in developing countries: An analytical overview, International Monetary Fund Staff Papers, 36, pp. 182-227.

Menon, J. (1996) The degree and determinants of exchange rate pass-through: market structure, non-tariff barriers, and multinational corporations, The Journal of the Royal Economic Society, 106(435), pp. 434-444.

Razmi, A. \& Blecker R. (2005) Developing country exports of manufactures: moving up the ladder to escape the fallacy of composition? Working Paper 2005-02, University of Massachusetts, Amherst.

Taylor, A. (2000) Low inflation, pass-through, and the pricing power of firms, European Economic Review, 44(7), pp. 1389-1408.

UNCTAD (2002) World investment report, Technical Report, United Nations Commission on Trade and Development, Geneva. 